\title{
The genomic basis for the evolution of a novel form of cellular reproduction in the bacterium Epulopiscium
}

\author{
David A Miller ${ }^{1}$, Garret Suen ${ }^{2}$, Kendall D Clements $^{3}$ and Esther R Angert ${ }^{1 *}$
}

\begin{abstract}
Background: Epulopiscium sp. type B, a large intestinal bacterial symbiont of the surgeonfish Naso tonganus, does not reproduce by binary fission. Instead, it forms multiple intracellular offspring using a process with morphological features similar to the survival strategy of endospore formation in other Firmicutes. We hypothesize that intracellular offspring formation in Epulopiscium evolved from endospore formation and these two developmental programs share molecular mechanisms that are responsible for the observed morphological similarities.

Results: To test this, we sequenced the genome of Epulopiscium sp. type B to draft quality. Comparative analysis with the complete genome of its close, endospore-forming relative, Cellulosilyticum lentocellum, identified homologs of well-known sporulation genes characterized in Bacillus subtilis. Of the 147 highly conserved B. subtilis sporulation genes used in this analysis, we found 57 homologs in the Epulopiscium genome and 87 homologs in the $C$. lentocellum genome.

Conclusions: Genes coding for components of the central regulatory network which govern the expression of forespore and mother-cell-specific sporulation genes and the machinery used for engulfment appear best conserved. Low conservation of genes expressed late in endospore formation, particularly those that confer resistance properties and encode germinant receptors, suggest that Epulopiscium has lost the ability to form a mature spore. Our findings provide a framework for understanding the evolution of a novel form of cellular reproduction.
\end{abstract}

Keywords: Developmental process, Endospore, Sporulation, Spore, Endospore-forming bacteria, Binary fission, Intracellular offspring

\section{Background}

Endospore formation is an ancient and complex developmental process exclusive to certain bacteria within the Firmicutes [1,2]. Endospores endure environmental conditions that would kill most other bacterial cells, including prolonged periods of insufficient nutrients, moderate levels of organic solvents, exposure to phage, extremes in $\mathrm{pH}$, proteases and cell wall degrading enzymes, freezing, desiccation and excessive heat or radiation $[3,4]$. This form of sporulation preserves the genome in a remarkably dispersible and dormant cell type that can resume vegetative growth when the environment improves.

\footnotetext{
* Correspondence: era23@cornell.edu

'Department of Microbiology, Cornell University, Ithaca, NY 14853, USA Full list of author information is available at the end of the article
}

While most sporulating species of Firmicutes produce a single endospore, some have the ability to produce multiple endospores [5]. For example, Clostridium oceanicum regularly forms two endospores, one at each end of the mother cell [6]. Others include the Segmented Filamentous Bacteria, a group of uncultivated inhabitants of the intestinal tract of animals [7]. These multicellular filaments live attached to the lining of the small intestine, and to disperse or reposition itself in the gut, each cell in a filament forms either an endospore containing two cells or two non-dormant intracellular offspring $[7,8]$.

Other lineages within the Firmicutes use multiple endospore formation as a reproductive strategy. The guinea pig intestinal symbiont Metabacterium polyspora may undergo binary fission but the regular formation of multiple endospores, up to nine from a single mother

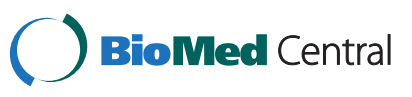


cell, is a significant form of reproduction $[9,10]$. The life history of $M$. polyspora may be selecting for this unusual mode of reproduction, which could improve survival as the bacteria cycle in and out of the host gastrointestinal tract [10]. A large and diverse group of surgeonfish intestinal symbionts related to $M$. polyspora display an array of reproductive modes that involve binary fission and/or sporulation [11]. Like $M$. polyspora, the identified morphotypes and phylotypes of these surgeonfish symbionts show host-specific distributions, and an individual fish acquires the symbionts by the ingestion of feces or detritus [11,12]. The type C Epulopiscium-like fish intestinal symbionts, rely solely on the formation of two endospores for reproduction and appear to have abandoned binary fission altogether [12]. The largest members of this group of symbionts, Epulopiscium spp. type A and type $\mathrm{B}$, are phylogenetically distinct from the smaller endospore-forming $\mathrm{C}$ morphotypes. Epulopiscium spp. type A and B appear to have taken the developmental process one step further and reproduce by the daily production of two or more intracellular offspring that are not dormant $[11,13]$. The phylogenetic relationship between multiple endospore formers and lineages that produce non-dormant intracellular offspring, and the morphological changes shared between these processes, suggest that the latter developmental process is related to endospore formation [13].

The stages of endospore formation (Figure 1) are described in the model organism Bacillus subtilis $[14,15]$ and these morphological transitions appear conserved in other endospore formers [16]. Cells that exhibit no overt signs of sporulation are defined as stage 0 . After initiation of sporulation, the chromosome replicates and replication origins become tethered to opposite poles of the cell. This unusual nucleoid conformation is called the axial filament and these cells are said to be in stage I [17]. Instead of dividing at the midcell, the sporulating cell divides near one pole, producing the forespore and larger mother cell, which marks stage II. Division traps approximately one-third of one of the chromosomes in the forespore [18]. The rest of the chromosome, still within the mother cell, is translocated into the forespore so that the spore contains a complete genome [19]. Enzymatic degradation of peptidoglycan between the mother cell and forespore results in curvature of the septum [20,21]. The mother-cell membrane then wraps around the forespore to completely engulf the forespore, which marks stage III [22]. In stage IV, a modified peptidoglycan called the cortex is synthesized in the space between the mother-cell and forespore membranes. In stage $\mathrm{V}$, a complex proteinaceous coat is applied to the developing spore [23,24]. Stage VI is defined as endospore maturation, when the spore gains many of its resistance traits [3]. Lastly, the mother cell lyses to release the mature spore, in stage VII.

The sequential activation of stage-specific transcription factors controls the proper timing and location of gene expression to ensure the progression of cellspecific developmental events. In B. subtilis, a network of kinases and phosphatases conveys information about intracellular and extracellular conditions to the phosphorelay, which ultimately determines the phosphorylation state of the transcription factor Spo0A [25-27]. While Spo0A is considered the master regulator of sporulation, it also regulates a number of alternative cellular reactions to environmental change [28]. In its active form, Spo0A $\sim \mathrm{P}$ either directly or indirectly affects the transcription of more than 500 genes [29]. Spo0A activation is essential for entry into sporulation.

After asymmetric division, gene expression is regulated by four sporulation-specific sigma factors: $\sigma^{\mathrm{F}}, \sigma^{\mathrm{E}}, \sigma^{\mathrm{G}}$, and $\sigma^{\mathrm{K}}$ (Figure 1) [30,31]. $\sigma^{\mathrm{F}}$ and $\sigma^{\mathrm{G}}$ are activated only in the forespore while $\sigma^{\mathrm{E}}$ and $\sigma^{\mathrm{K}}$ are activated only in the mother cell. Both $\sigma^{\mathrm{F}}$ and $\sigma^{\mathrm{E}}$ are expressed prior to asymmetric division [32], but $\sigma^{\mathrm{F}}$ is held inactive in a complex with two peptides of its anti-sigma factor SpoIIAB [33] and $\sigma^{\mathrm{E}}$ is synthesized as an inactive pro-peptide [34]. The forespore sigma, $\sigma^{\mathrm{F}}$, is the first to be activated. SpoIIE phosphorylates SpoIIAA (the $\sigma^{\mathrm{F}}$ anti-anti-sigma factor), which binds SpoIIAB leading to the release of $\sigma^{\mathrm{F}}$ [35-37]. SpoIIR, part of the $\sigma^{\mathrm{F}}$ regulon [38], is produced in the forespore and inserted into the sporulation septum, where it activates SpoIIGA in the mother cell [39]. SpoIIGA then cleaves pro- $\sigma^{\mathrm{E}}$ thus releasing mature $\sigma^{\mathrm{E}}$ to the cytoplasm [40]. Likewise, the late-sporulation sigma factors, $\sigma^{\mathrm{G}}$ and $\sigma^{\mathrm{K}}$, are not immediately functional when expressed and activation of each entails factor-specific intracellular signaling cascades and release mechanisms [41-48].

Tighter control of particular genes in each regulon is provided by additional transcription factors [49-53] that form both coherent and incoherent feed-forward loops with their associated sigma factor [1]. Coherent feed-forward loops occur when a sigma factor regulates expression of a gene and then combines with that gene product to up-regulate more genes. Incoherent feed-forward loops come about when such a combination leads to the down-regulation of additional genes $[1,53]$. For example, $r s f A$ and spoIIR are both expressed from $\sigma^{\mathrm{F}}$ promoters $[38,49]$. However, RsfA combined with $\sigma^{\mathrm{F}}$ turns off transcription of spoIIR, so only a brief burst of spoIIR expression is seen immediately following asymmetric division. Such feed-forward loops allow the cell to modulate the timing, duration and location of expression of subsets of genes within a regulon. The combination of all central transcriptional regulatory 


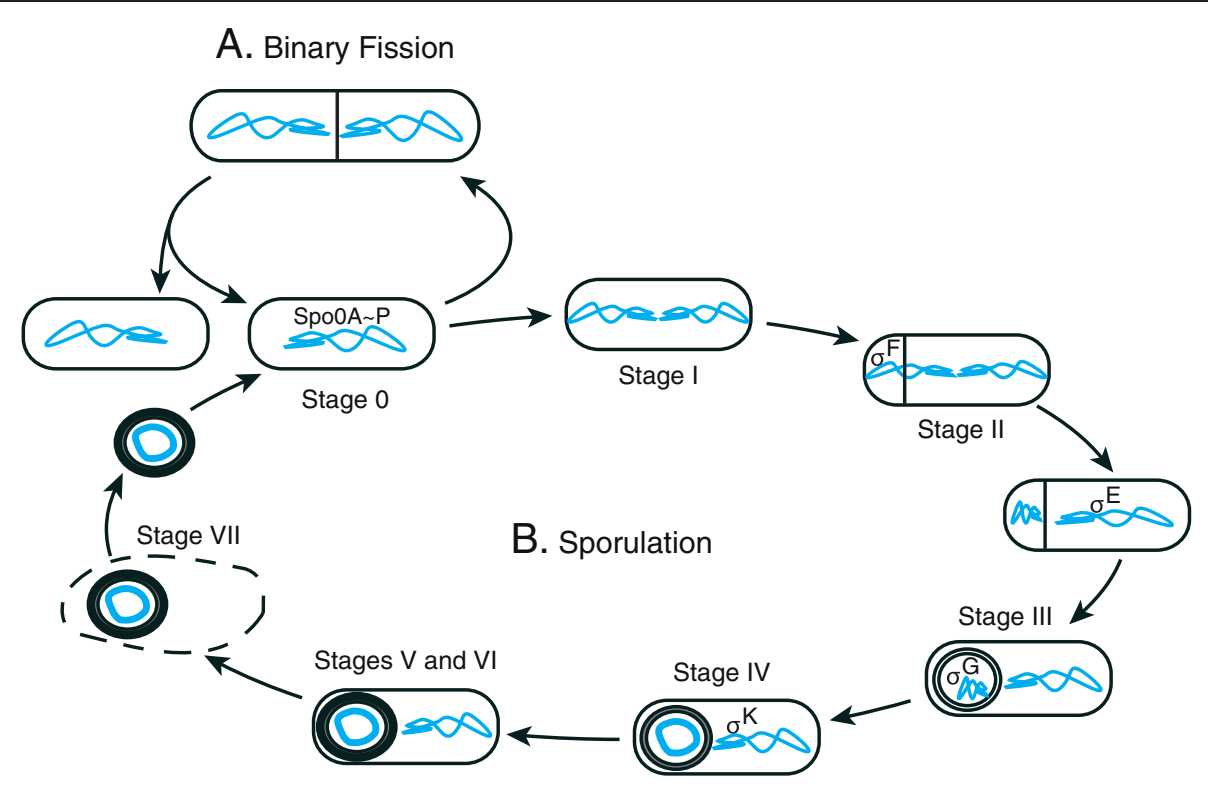

\section{Intracellular Offspring Formation}

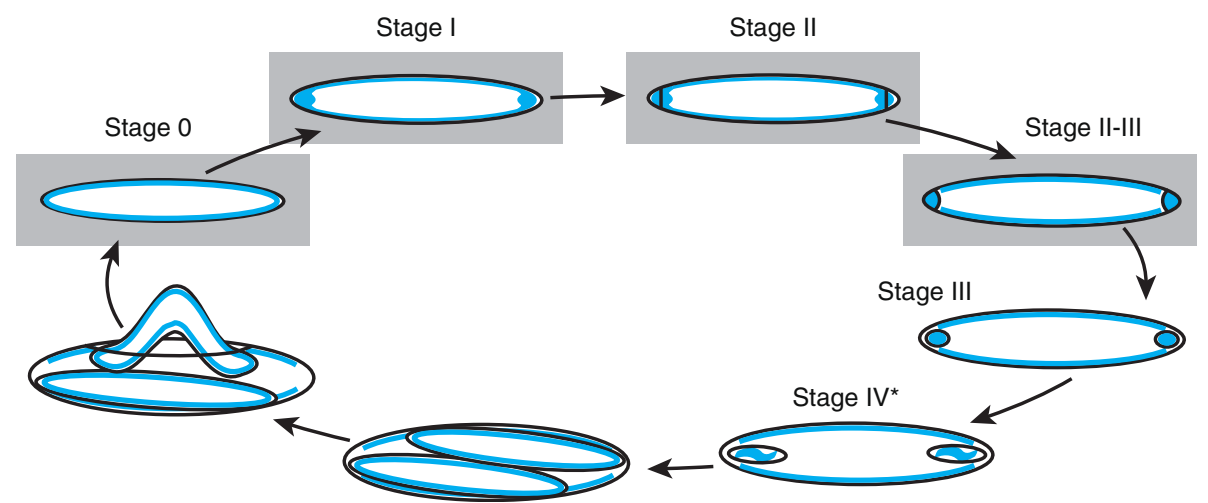

Figure 1 The life cycles of B. subtilis and Epulopiscium sp. type B. A) In a favorable environment, B. subtilis undergoes growth and division. B) When nutrient limitations become critical, the cell may develop an endospore. Shown here are the morphological stages described for sporulation. The temporal and spatial activation of Spo0A and the four sporulation-specific sigma factors are shown. The grey circle around the forespore indicates the cortex. The thick black circle around the forespore at stage $\mathrm{V}$ and beyond represents the spore coat. C) Earliest stages of offspring development in Epulopiscium sp. type B are based on the similar morphological transitions described for sporulation in B. subtilis. See text for a detailed explanation of the process. Offspring frequently initiate the next round of reproduction prior to exiting the mother cell. Those stages that are seen in offspring still within their mother cell are highlighted with grey boxes. For all diagrams, DNA is shown in blue.

mechanisms modulates the expression of more than 700 genes during sporulation.

The B. subtilis model can serve as a foundation for exploring mechanistic modifications required to support the formation of multiple endospores or intracellular offspring [13]. For example, Epulopiscium sp. type B are intestinal symbionts of the unicornfish Naso tonganus and can reach lengths of $200-300 \mu \mathrm{m}$ and widths of 50$60 \mu \mathrm{m}[11,54]$. While the production of endospores has been observed in related morphotypes [12], Epulopiscium sp. type B does not produce endospores and does not reproduce by binary fission (Figure 1). Instead, each cell forms two or more intracellular offspring in a process that repeats daily [54-56].

The formation of these offspring has been described in stages that parallel stages of endospore formation [5456]. Stage 0 mother cells contain large offspring (daughter cells) that show no signs of the initiation of the next generation of offspring (i.e. granddaughter cells). Stage I is defined as offspring cells that have coalesced DNA at the poles. Stage II cells have straight polar septa, but not all polar DNA is inside the newly formed offspring. 
Stage II-III includes cells with curved polar septa, indicating the start of polar cell engulfment, and all polar DNA has been translocated into the offspring. Stage III cells contain small, fully engulfed offspring, with a length-to-width ratio of less than 2:1 while the offspring in stage IV* cells have a ratio greater than 2:1. After engulfment, the two processes diverge and changes occurring in Epulopiscium are not well understood so later stages are not indicated in this model. Offspring continue to grow until they fill the mother-cell cytoplasm. In time, the mother-cell envelope splits open and the offspring are released.

Previous work has shown that the division protein FtsZ localizes to the poles of an Epulopiscium cell in a similar way to FtsZ in B. subtilis during endospore formation [54]. In B. subtilis, both potential division sites appear fully functional and a second, partial polar septum occasionally forms at the forespore-distal pole although the second septum eventually regresses $[57,58]$. With Epulopiscium, rapid sequential or simultaneous bipolar division occurs [54]. Putative homologs for SpoIIE, SpoIIAA, SpoIIAB and $\sigma^{\mathrm{F}}$ also have been identified in the Epulopiscium genome [55]. Moreover, the expression pattern of spoIIE in Epulopiscium during offspring formation [55] is very similar to that seen in sporulating $B$. subtilis [59]. These results suggest that Epulopiscium uses cell-specific activation of alternative sigma factors in offspring development.

Here we sequenced and examined the draft genome of Epulopiscium sp. type B to determine the extent of conservation of the sporulation genetic program. A list of conserved "core" sporulation genes was assembled and used to determine which of the core sporulation genes are conserved in the Epulopiscium genome and its spore-forming relative Cellulosilyticum lentocellum DSM 5427. As predicted, we found a number of homologs to genes with sporulation-specific functions in Epulopiscium and even more of the core genes conserved in $C$. lentocellum. These results begin to define the genetic mechanisms that may be used for offspring production and development in Epulopiscium.

\section{Results and discussion}

\section{Epulopiscium sp. type B draft genome}

The draft genome of Epulopiscium sp. type B was used to assess the conservation of sporulation gene homologs in this bacterium. Epulopiscium sp. type B has become our model for genome studies because $N$. tonganus harbors morphologically and genetically homogenous populations of these Epulopiscium cells. Clone libraries of $16 \mathrm{~S}$ rRNA gene fragments generated from amplified DNA using primers (27F and $1492 \mathrm{R}$ ) to conserved regions of the gene consistently yield a single phylotype $[60,61]$. Although the genome was not assembled completely, the project produced approximately $2.7 \mathrm{Mbp}$ of sequence in 92 large contigs ranging from $12-119 \mathrm{~kb}$ in length. The remaining data, consisting of small contigs less than $12 \mathrm{~kb}$ and well-represented single reads (singletons), comprise another 13.7 Mbp. This data set likely represents the Epulopiscium genome and may contain some highly repetitive DNA from the fish host or other abundant inhabitants of the $N$. tonganus intestinal tract that may have been carried along during Epulopiscium cell isolation.

To determine the completeness of the Epulopiscium draft genome, we analyzed the 92 large contigs using two approaches. First, we identified the total number of rRNAs and tRNAs encoded by the genome. We found four 5 S, four 23S, and three 16S rRNA genes in addition to 31 tRNAs covering all amino acids except histidine, phenylalanine, and serine. These values are about onethird less the rRNAs and tRNAs encoded by $C$. lentocellum DSM 5427, the closest relative with a complete genome sequence [62]. We also analyzed the small contigs and singletons in the Epulopiscium draft genome and found additional functional RNAs. This resulted in a grand total of nine $5 \mathrm{~S}$, five $16 \mathrm{~S}$ and five $23 \mathrm{~S}$ rRNAs, as well as 66 tRNAs covering all amino acids for the Epulopiscium draft genome. These numbers should be viewed with caution as some copies may represent overlapping contigs that did not assemble. Second, we performed a clusters of orthologous genes (COG) analysis using the predicted proteome from the 92 large contigs of the Epulopiscium draft genome and compared the percent proteins encoded in each category against a similar analysis of all completely sequenced genomes in either the phylum Firmicutes or the genus Clostridium (Table 1). We found that the percentage of proteins in each COG category in the Epulopiscium draft genome was comparable to the percentages of either the Firmicutes or the Clostridia. One noteworthy difference was seen in the category of carbohydrate transport and metabolism, which was exceptionally high in Epulopiscium, compared to the other Firmicutes groups. Taken together, these data indicate that this draft is somewhat incomplete, although it is difficult to say with absolute certainty the level of completeness.

For the identification of potential sporulation gene homologs in Epulopiscium, contigs and singletons were concatenated into a single pseudomolecule. The position of each junction between adjacent fragments was noted so that any chimeric open reading frames formed during pseudomolecule assembly could be identified.

\section{The core sporulation gene list}

As a starting point, a comprehensive list of sporulation genes was compiled based on previous studies of $B$. subtilis 168 and its derivatives, since this is by far the most 
Table 1 COG analysis of the Epulopiscium sp. type B genome

\begin{tabular}{|c|c|c|c|c|}
\hline COG Category & Code & Epulopiscium sp. type B & Clostridium & Firmicutes \\
\hline \multicolumn{5}{|l|}{ Information storage and processing } \\
\hline Translation, ribosomal structure and biogenesis & J & $7.57 \%$ & $5.91 \%$ & $6.95 \%$ \\
\hline RNA processing and modification & A & $0.00 \%$ & $0.00 \%$ & $0.00 \%$ \\
\hline Transcription & $\mathrm{K}$ & $5.35 \%$ & $9.19 \%$ & $8.05 \%$ \\
\hline Replication, recombination and repair & $\mathbf{L}$ & $4.17 \%$ & $5.43 \%$ & $6.20 \%$ \\
\hline Chromatin structure and dynamics & B & $0.00 \%$ & $0.03 \%$ & $0.03 \%$ \\
\hline \multicolumn{5}{|l|}{ Cellular processes and signaling } \\
\hline Cell cycle control, cell division, chromosome partitioning & D & $1.94 \%$ & $1.24 \%$ & $1.29 \%$ \\
\hline Nuclear structure & $\mathrm{Y}$ & $0.00 \%$ & $0.00 \%$ & $0.00 \%$ \\
\hline Defense mechanisms & v & $1.60 \%$ & $2.81 \%$ & $2.39 \%$ \\
\hline Signal transduction mechanisms & $\mathbf{T}$ & $5.42 \%$ & $6.92 \%$ & $4.89 \%$ \\
\hline Cell wall/membrane/envelope biogenesis & M & $5.49 \%$ & $5.60 \%$ & $5.36 \%$ \\
\hline Cell motility & $\mathrm{N}$ & $4.31 \%$ & $2.73 \%$ & $1.51 \%$ \\
\hline Cytoskeleton & $\mathbf{Z}$ & $0.00 \%$ & $0.01 \%$ & $0.01 \%$ \\
\hline Extracellular structures & w & $0.00 \%$ & $0.00 \%$ & $0.00 \%$ \\
\hline Intracellular trafficking, secretion, and vesicular transport & $\mathbf{U}$ & $1.74 \%$ & $1.44 \%$ & $1.53 \%$ \\
\hline Posttranslational modification, protein turnover, chaperones & 0 & $3.13 \%$ & $2.76 \%$ & $2.99 \%$ \\
\hline \multicolumn{5}{|l|}{ Metabolism } \\
\hline Energy production and conversion & $\mathrm{C}$ & $5.97 \%$ & $5.94 \%$ & $5.17 \%$ \\
\hline Carbohydrate transport and metabolism & G & $16.60 \%$ & $7.26 \%$ & $8.09 \%$ \\
\hline Amino acid transport and metabolism & $\mathrm{E}$ & $10.56 \%$ & $8.42 \%$ & $8.86 \%$ \\
\hline Nucleotide transport and metabolism & $\mathbf{F}$ & $2.78 \%$ & $2.84 \%$ & $3.33 \%$ \\
\hline Coenzyme transport and metabolism & $\mathbf{H}$ & $5.00 \%$ & $4.13 \%$ & $4.10 \%$ \\
\hline Lipid transport and metabolism & I & $2.22 \%$ & $1.97 \%$ & $2.36 \%$ \\
\hline Inorganic ion transport and metabolism & $\mathbf{P}$ & $5.28 \%$ & $4.87 \%$ & $5.22 \%$ \\
\hline Secondary metabolites biosynthesis, transport and catabolism & Q & $0.49 \%$ & $1.03 \%$ & $1.10 \%$ \\
\hline \multicolumn{5}{|l|}{ Poorly characterized } \\
\hline General function prediction only & $\mathbf{R}$ & $11.46 \%$ & $11.09 \%$ & $11.20 \%$ \\
\hline Function unknown & $\mathbf{S}$ & $6.53 \%$ & $8.36 \%$ & $9.39 \%$ \\
\hline Total Genomes Analyzed & & 1 & 32 & 300 \\
\hline
\end{tabular}

thoroughly characterized sporulation program for any member of the Firmicutes. The initial list of 732 genes included those described using classic genetic approaches as well as putative sporulation genes uncovered in transcriptional array analyses of sporulation regulons [29,53,63-65]. BLAST searches refined the list, narrowing it to genes that are conserved in both endospore-forming Bacilli and Clostridia. Further refinement of the list eliminated genes with homologs in nonspore-forming Firmicutes.

Several notable genes that were eliminated are essential in the B. subtilis model of sporulation, including the phosphorelay protein SpoOB, and associated histidine kinases, transcription factors RsfA, GerR and GerE, and the intercellular signal transduction proteins SpoIIQ and SpoIVFA. Our inability to identify a SpoIIQ homolog agrees with the results of a previous study [1]. Likewise, the limited distribution of $B$. subtilis phosphorelay homologs among endospore-forming bacteria has been noted previously [66,67] and it is likely that clostridia use a different set of kinases for activation of Spo0A $[68,69]$. For example, recent genetic studies demonstrated phosphorylation of SpoOA in C. acetobutylicum by novel orphan histidine kinases $[68,69]$.

A few key early sporulation proteins (Spo0A, Spo0J, Soj, SpoIIIE and SpoIIIJ), known to function during normal growth in B. subtilis, were placed back on the core list. All of these are part of the $\sigma^{\mathrm{A}}$ regulon and were first identified as essential for efficient sporulation. Spo0A determines entry into sporulation. Soj and Spo0J are members of the ParA/B family of partitioning proteins that regulate transcription of early sporulation genes and 
assist in maintaining chromosome architecture [31]. The FtsK homolog SpoIIIE aids in chromosome separation during binary fission [70], and during sporulation it is responsible for chromosome translocation into the developing forespore $[18,19]$. The location of genes on the chromosome and timing of translocation affects cellspecific expression of genes, which impacts key molecular events such as the activation of sporulation sigma factors [71-73]. SpoIII is a membrane protein translocase that, in addition to its vegetative growth function, appears to play a key role in the activation of $\sigma^{G}$ during sporulation $[41,74]$. In the end, our core list included 147 genes (Table 2).

\section{An overview of the core sporulation genes found in Epulopiscium and C. lentocellum}

We were concerned that the phylogenetic distance between B. subtilis and Epulopiscium may bias the distribution of conserved genes we would be able to identify. To gauge how much evolutionary divergence is impacting the recovery of homologs in Epulopiscium, we compared our core list of sporulation genes to the C. lentocellum genome as well. Cellulosilyticum lentocellum DSM 5427 is the closest endosporeforming relative of Epulopiscium with an available completely sequenced genome [62]. Epulopiscium sp. type B and C. lentocellum are members of the family Lachnospiraceae and the two share 91\% 16S rRNA sequence identity. Of the 4,185 predicted protein-coding genes in the C. lentocellum genome, an Epulopiscium sp. type B gene is the top BLAST hit for 546 of these genes (data not shown).

Of the 147 core sporulation genes, we found 87 homologs in the C. lentocellum genome and 57 putative homologs in the Epulopiscium sp. type B genome (Table 3). All of the sporulation genes found in the Epulopiscium genome were also found in the C. lentocellum genome. In the list of conserved genes, two code for members of a family of functionally redundant small acid-soluble proteins (SASPs) that bind to and protect spore DNA from damage [4,75]. One of the SASPs is similar to two paralogs of this family from $B$. subtilis and is represented as $s s p C / F$. In both Epulopiscium and C. lentocellum, at least five genes are represented from each of the four sporulation sigma factor regulons, as well as genes in the Spo0A regulon with $\sigma^{\mathrm{H}}$ and $\sigma^{\mathrm{A}}$ promoters. Of the C. lentocellum homologs not seen in the Epulopiscium genome, 14 code for " $y$ " genes that are expressed during sporulation, although their roles have yet to be characterized. These genes are equally distributed between pre- and post-engulfment regulons, but only two are expressed in the forespore in $B$. subtilis.

\section{Conservation of the master regulator Spo0A in Epulopiscium}

Although clostridia do not have a phosphorelay system homologous to that used by B. subtilis, Spo0A is conserved in the genomes of all known endospore-forming bacteria. The Epulopiscium sp. type B genome contains an unambiguous Spo0A homolog (Figure 2). The Epulopiscium Spo0A homolog is $51 \%$ identical to Spo0A of B. subtilis. Conserved residues in both phospho-acceptor and DNA binding domains [76] are located in the putative Epulopiscium Spo0A homolog as well. This suggests that although offspring production seems hard-wired in Epulopiscium and there is no obvious need to adapt the timing of entry into offspring production to environmental conditions, Spo0A is still important for initiating this process or possibly other metabolic transitions. $\mathrm{Ba}$ cillus spp. use the phosphorylation state and abundance of Spo0A to engage in activities, such as cannibalism, to maintain a growing population for as long as possible prior to resorting to sporulation [26]. In clostridia, Spo0A also dictates metabolic transitions [77]. For example, in Clostridium acetobutylicum, Spo0A activation shifts the cell from acid production during exponential phase growth to solvent production during stationary phase in addition to entry into sporulation [78]. We searched the Epulopiscium genome for homologs of the newly discovered $C$. acetobutylicum Spo0A kinases that are important for developmental and metabolic transitions [69], however none of these appear to be conserved in the Epulopiscium genome. The future identification and characterization of kinases or phosphatases in Epulopiscium that interact with Spo0A may provide information about the environmental and cellular cues that regulate population level developmental or physiological transitions.

\section{The central regulatory network conserved in endospore- forming bacteria appears conserved in Epulopiscium}

In $B$. subtilis, the sequential activation of cell-specific sigma factors directs compartmentalized gene expression that determines the different fates of the mother cell and forespore [1]. The presence of homologous genes suggests a similar system likely also functions in Epulopiscium developmental progression (Figure 3). In a previous publication, we described the $\sigma^{\mathrm{F}}$ homolog of Epulopiscium and a structural analysis of the proteins required for $\sigma^{\mathrm{F}}$ activation: SpoIIE, SpoIIAA, and SpoIIAB [55]. In the present study, we uncovered genes coding for all additional sporulation sigma factors $\left(\sigma^{\mathrm{E}}\right.$, $\sigma^{\mathrm{G}}$ and $\sigma^{\mathrm{K}}$ ) and homologs for the intercellular signal transduction proteins responsible for the activation of $\sigma^{\mathrm{E}}$ (SpoIIR and SpoIIGA) and $\sigma^{G}$ (SpoIIIAA-AH and SpoIIIJ). In B. subtilis, SpoIIQ interacts with SpoIIIAA$\mathrm{AH}$ in an intracellular signaling system required for the 
Table 2 Core sporulation genes identified in the

\section{B. subtilis 168 genome}

\begin{tabular}{|c|c|c|}
\hline GENE & REG & FUNCTION \\
\hline aprX & K & alkaline serine protease \\
\hline bofA & $E$ & inhibitor of the pro- $\sigma^{k}$ processing machinery \\
\hline cotl & K & spore coat protein \\
\hline $\cot B$ & $\mathrm{E}$ & component of the inner spore coat \\
\hline $\cot C$ & $E$ & component of the inner spore coat \\
\hline $\operatorname{cots}$ & K & spore coat protein \\
\hline $\operatorname{csfB}$ & $\mathrm{F}$ & anti- $\sigma^{G}$ factor \\
\hline CWID & $E, G$ & $\mathrm{~N}$-acetylmuramoyl-L-alanine amidase/germination \\
\hline cWlJ & $\mathrm{E}$ & cell wall hydrolase/germination, cortex lytic \\
\hline$d a c B$ & E & $\begin{array}{l}\text { D-alanyl-D-alanine carboxypeptidase } \\
\text { (penicillin-binding protein 5) }\end{array}$ \\
\hline dacF & $F, G$ & $\begin{array}{l}\text { D-alanyl-D-alanine carboxypeptidase } \\
\text { (penicilin-binding protein) }\end{array}$ \\
\hline gerAA & $F, G$ & component of the germination receptor GerA \\
\hline ger $A B$ & $F, G$ & component of the germination receptor GerA \\
\hline gerAC & $F, G$ & component of the germination receptor GerA \\
\hline gerBA & G & component of germinant receptor B \\
\hline gerBB & G & component of germinant receptor B \\
\hline gerBC & G & $\begin{array}{l}\text { lipoprotein component of the germination } \\
\text { receptor B }\end{array}$ \\
\hline gerkA & G & spore germination receptor subunit \\
\hline gerkB & G & spore germination receptor subunit \\
\hline gerkC & G & spore germination receptor subunit \\
\hline$g p r$ & $F, G$ & germination protease \\
\hline jag & A & SpolllJ-associated RNA/ssDNA-binding protein \\
\hline kamA & $\mathrm{E}$ & lysine 2,3-aminomutase \\
\hline kapD & $\mathrm{E}, \mathrm{K}$ & inhibitor of the KinA pathway to sporulation \\
\hline $\operatorname{lon} B$ & $\mathrm{~F}$ & ATP-dependent protease/forespore-specific \\
\hline mmgC & $\mathrm{E}$ & short chain acyl-CoA dehydrogenase \\
\hline$n t d A$ & $\mathrm{E}$ & $\begin{array}{l}\text { biosynthesis of neotrehalosadiamine } \\
\text { (amino-sugar antibiotic)/aminotransferase }\end{array}$ \\
\hline$p b p G$ & $F, G$ & penicillin-binding protein (also known as ywhE) \\
\hline pbpl & $E, F$ & $\begin{array}{l}\text { penicillin-binding protein } \mathrm{PBP} 4 \mathrm{~B} / \text { mother } \\
\text { cell specific }\end{array}$ \\
\hline$p d a A$ & G & $\begin{array}{l}\text { exported } \mathrm{N} \text {-acetylmuramic acid } \\
\text { deacetylase/cortex lysis }\end{array}$ \\
\hline prkA & $\mathrm{E}$ & serine protein kinase/not well characterized \\
\hline sigE & $A, O A$ & sporulation sigma factor/mother cell only \\
\hline sigF & $\mathrm{H}, \mathrm{OA}$ & sporulation sigma factor/forespore only \\
\hline $\operatorname{sig} G$ & $F, G$ & sporulation sigma factor/forespore only \\
\hline sigk & $\mathrm{E}, \mathrm{K}$ & sporulation sigma factor/mother cell only \\
\hline sleB & G & spore cortex-lytic enzyme \\
\hline soj & $\mathrm{A}, \mathrm{OA}$ & $\begin{array}{l}\text { chromosome partitioning protein/transcriptional } \\
\text { regulator/negative regulation of sporulation } \\
\text { initiation }\end{array}$ \\
\hline$s p / B$ & G & spore photoproduct (thymine dimer) lyase \\
\hline spmA & $E$ & spore maturation protein/spore dehydration \\
\hline
\end{tabular}

Table 2 Core sporulation genes identified in the

\section{B. subtilis 168 genome (Continued)}

\begin{tabular}{|c|c|c|}
\hline spmB & E & spore maturation protein/spore dehydration \\
\hline spoOA & $\mathrm{A}, \mathrm{H}, \mathrm{OA}$ & $\begin{array}{l}\text { two-component response regulator central for } \\
\text { the initiation of sporulation/"master regulator" }\end{array}$ \\
\hline spoOF & $\mathrm{H}, \mathrm{OA}$ & $\begin{array}{l}\text { two-component response regulator involved } \\
\text { pathway leading to phosphorylation of SpoOA }\end{array}$ \\
\hline spoos & A & $\begin{array}{l}\text { site-specific DNA-binding protein/chromosome } \\
\text { positioning near the pole and transport through } \\
\text { the polar septum/antagonist of Soj-dependent } \\
\text { inhibition of sporulation initiation }\end{array}$ \\
\hline spollAA & $\mathrm{H}, \mathrm{OA}$ & anti-anti-sigma factor (antagonist of SpollAB) \\
\hline spollaB & $\mathrm{H}, \mathrm{OA}$ & anti- $\sigma^{F}$ factor \\
\hline spollD & $\mathrm{E}$ & $\begin{array}{l}\text { autolysin required for complete dissolution } \\
\text { of the sporulation septum }\end{array}$ \\
\hline spolle & $\mathrm{A}, \mathrm{OA}$ & $\begin{array}{l}\text { serine phosphatase }\left(\sigma^{F} \text { activation)/polar }\right. \\
\text { septum formation }\end{array}$ \\
\hline spol/GA & $\mathrm{A}, \mathrm{OA}$ & protease processing pro- $\sigma^{E}$ \\
\hline spolllAA & $\mathrm{E}$ & $\begin{array}{l}\text { ATP-binding stage } 1 \mathrm{II} \text { sporulation protein/mother } \\
\text { cell signalling for } \sigma^{G} \text { activation }\end{array}$ \\
\hline spolllaB & E & $\begin{array}{l}\text { stage III sporulation protein/mother cell } \\
\text { signalling for } \sigma^{G} \text { activation }\end{array}$ \\
\hline spolllaC & E & $\begin{array}{l}\text { stage III sporulation protein/mother cell } \\
\text { signalling for } \sigma^{G} \text { activation }\end{array}$ \\
\hline spolllaD & E & $\begin{array}{l}\text { stage III sporulation protein/mother cell } \\
\text { signalling for } \sigma^{G} \text { activation }\end{array}$ \\
\hline spollIAE & E & $\begin{array}{l}\text { stage III sporulation protein/mother cell } \\
\text { signalling for } \sigma^{G} \text { activation }\end{array}$ \\
\hline spollIAF & $\mathrm{E}$ & $\begin{array}{l}\text { stage III sporulation protein/mother cell } \\
\text { signalling for } \sigma^{G} \text { activation }\end{array}$ \\
\hline spolllaG & E & $\begin{array}{l}\text { stage III sporulation engulfment assembly } \\
\text { protein/mother cell signalling for } \sigma^{G} \text { activation }\end{array}$ \\
\hline spolllAH & E & $\begin{array}{l}\text { stage III sporulation ratchet engulfment } \\
\text { protein/mother cell signalling for } \sigma^{G} \text { activation }\end{array}$ \\
\hline spollID & E & $\begin{array}{l}\text { transcriptional regulator of } \sigma^{\mathrm{E}} \text { and } \\
\sigma^{\mathrm{K}} \text {-dependent genes }\end{array}$ \\
\hline spollle & A & spore DNA translocase \\
\hline spolll] & A & protein translocase/essential for activation of $\sigma^{G}$ \\
\hline spollm & E & autolysin for dissolution of the septal cell wall \\
\hline spollP & $E, F, G$ & spore autolysin \\
\hline spollR & $\mathrm{F}$ & endopeptidase/activation of $\sigma^{E}$ \\
\hline spolva & E & $\begin{array}{l}\text { morphogenetic protein required for proper } \\
\text { spore cortex formation and coat assembly }\end{array}$ \\
\hline spolvB & $F, G, O A$ & $\begin{array}{l}\text { regulatory membrane-associated serine protease) } \\
\text { intercompartmental signalling of pro- } \sigma^{\mathrm{K}} \\
\text { processing and activation in the mother-cell }\end{array}$ \\
\hline spolvFB & $\mathrm{E}$ & $\begin{array}{l}\text { membrane metalloprotease required for } \\
\text { the processing of pro- } \sigma^{k}\end{array}$ \\
\hline spoVAA & G & dipicolinic acid uptake by the developing spore \\
\hline spoVAB & G & dipicolinic acid uptake by the developing spore \\
\hline spoVAC & G & dipicolinic acid uptake by the developing spore \\
\hline spoVAD & G & dipicolinic acid uptake by the developing spore \\
\hline SPOVAEB & & dipicolinic acid uptake by the developing spore \\
\hline
\end{tabular}


Table 2 Core sporulation genes identified in the

\section{B. subtilis 168 genome (Continued)}

\begin{tabular}{|c|c|c|}
\hline spoVAF & G & dipicolinic acid uptake by the developing spore \\
\hline spovB & $\mathrm{E}$ & spore cortex synthesis \\
\hline spoVD & $\mathrm{E}$ & penicillin-binding protein \\
\hline spoVE & E & spore cortex peptidoglycan synthesis \\
\hline spoVFA & K & spore dipicolinate synthase subunit A \\
\hline spoVFB & K & spore dipicolinate synthase subunit B \\
\hline spoVR & E & spore cortex synthesis \\
\hline spovs & $\mathrm{H}$ & $\begin{array}{l}\text { regulator required for dehydration of the spore } \\
\text { core and assembly of the coat }\end{array}$ \\
\hline spoVt & $F, G$ & transcriptional regulator of $\sigma^{G}$-dependent genes \\
\hline spsF & K & $\begin{array}{l}\text { putative glycosyltransferase/spore coat } \\
\text { polysaccharide synthesis }\end{array}$ \\
\hline spsG & $E, K$ & $\begin{array}{l}\text { putative glycosyltransferase/spore coat } \\
\text { polysaccharide synthesis }\end{array}$ \\
\hline sps」 & $\mathrm{E}, \mathrm{K}$ & $\begin{array}{l}\text { putative dTDP-glucose } 4,6 \text {-dehydratase/spore } \\
\text { coat polysaccharide synthesis }\end{array}$ \\
\hline sspA & G & small acid-soluble spore protein (alpha-type SASP) \\
\hline $\operatorname{ssp} B$ & G & small acid-soluble spore protein (beta-type SASP) \\
\hline $\operatorname{sspC}$ & G & $\begin{array}{l}\text { small acid-soluble spore protein } \\
\text { (alpha/beta-type SASP)/SP } \beta \text { phage protein }\end{array}$ \\
\hline$s s p D$ & G & $\begin{array}{l}\text { small acid-soluble spore protein } \\
\text { (alpha/beta-type SASP) }\end{array}$ \\
\hline sspF & G & $\begin{array}{l}\text { small acid-soluble spore protein } \\
\text { (alpha/beta-type SASP) }\end{array}$ \\
\hline$t / p$ & $F, G$ & small acid-soluble spore protein \\
\hline yaaH & E & spore peptidoglycan hydrolase \\
\hline yabG & K & sporulation-specific protease \\
\hline yabP & E & $\begin{array}{l}\text { spore protein involved in the shaping of } \\
\text { the spore coat }\end{array}$ \\
\hline yabQ & E & $\begin{array}{l}\text { membrane protein of the forespore/essential } \\
\text { for spore cortex }\end{array}$ \\
\hline ybaN & E & $\begin{array}{l}\text { polysaccharide deacetylase involved } \\
\text { in sporulation }\end{array}$ \\
\hline$y b d M$ & G & putative protein kinase \\
\hline ycgF & $\mathrm{E}$ & putative amino acid export permease \\
\hline ydfS & K, G & hypothetical protein \\
\hline$y d h D$ & $\mathrm{E}$ & spore cortex lytic enzyme \\
\hline yerB & $O A$ & putative lipoprotein \\
\hline$y f k Q$ & G & putative spore germination protein \\
\hline$y f k R$ & G & putative spore germination protein \\
\hline$y f k T$ & G & $\begin{array}{l}\text { putative spore germination integral inner } \\
\text { membrane protein }\end{array}$ \\
\hline$y f n G$ & K & putative sugar-phosphate cytidylyltransferase \\
\hline$y f n H$ & K & putative FAD-dependent oxido-reductase \\
\hline ygak & K & putative FAD-dependent oxido-reductase \\
\hline yhbH & E & hypothetical protein \\
\hline$y h c B$ & G & putative oxidoreductase associated \\
\hline yhcV & G & putative oxidoreductase \\
\hline
\end{tabular}

Table 2 Core sporulation genes identified in the B. subtilis 168 genome (Continued)

\begin{tabular}{|c|c|c|}
\hline$y h f W$ & $\mathrm{~F}$ & putative Rieske [2Fe-2S] oxygenase \\
\hline yis $Y$ & E & putative hydrolase \\
\hline$y k u D$ & K & murein transglycosylase \\
\hline ykuS & $\mathrm{F}$ & hypothetical protein \\
\hline$y k v U$ & $\mathrm{E}$ & spore membrane protein involved in germination \\
\hline ylak & E & putative phosphate starvation inducible protein \\
\hline$y / b B$ & $\mathrm{~F}$ & putative oxidoreductase \\
\hline$y / b J$ & E & putative factor required for spore cortex formation \\
\hline$y m x H$ & E & hypothetical protein \\
\hline$y n d D$ & G & putative spore germination protein \\
\hline yndE & G & $\begin{array}{l}\text { putative spore germination integral inner } \\
\text { membrane protein }\end{array}$ \\
\hline yndF & G & putative spore germination lipoprotein \\
\hline yngE & $\mathrm{E}$ & putative propionyl-CoA carboxylase \\
\hline yngl & E & AMP-binding domain protein \\
\hline yng & E & acyl-CoA dehydrogenase, short-chain specific \\
\hline yoaR & G & $\begin{array}{l}\text { putative factor for cell wall maintenance } \\
\text { or synthesis }\end{array}$ \\
\hline yobN & E & putative amine oxidase \\
\hline урев & G & spore membrane component \\
\hline yqfC & E & hypothetical protein \\
\hline yqfD & E & stage IV sporulation protein \\
\hline yagt & E & $\begin{array}{l}\text { putative gamma-D-glutamyl-L-diamino } \\
\text { acid endopeptidase }\end{array}$ \\
\hline yqho & E & hypothetical protein \\
\hline yraD & G & putative spore coat protein \\
\hline yrbG & $E, G$ & hypothetical protein \\
\hline yrkC & K & putative dioxygenase; cupin family \\
\hline$y t c A$ & K & putative UDP-glucose dehydrogenase \\
\hline ytcC & K & putative glucosyltransferase \\
\hline$y t f J$ & $\mathrm{~F}$ & hypothetical protein \\
\hline yt/A & K & putative $A B C$ transporter component \\
\hline$y t / C$ & K & $\begin{array}{l}\text { putative } A B C \text { transporter component, } \\
\text { ATP-binding }\end{array}$ \\
\hline$y t / D$ & K & putative permease of $A B C$ transporter \\
\hline$y t v l$ & E & putative permease \\
\hline$y t \times C$ & E & hypothetical protein \\
\hline yunB & $E, K$ & putative protein involved in spore formation \\
\hline yuth & $\mathrm{F}$ & spore coat-associated protein \\
\hline ywjD & G & putative UV damage endonuclease \\
\hline yyac & $\mathrm{F}$ & hypothetical protein \\
\hline yyaE & E & putative oxidoreductase \\
\hline yyaO & K & hypothetical protein \\
\hline$y y B$ & E & inner spore coat protein \\
\hline
\end{tabular}


Table 3 Genes conserved in Epulopiscium and C. lentocellum

\begin{tabular}{|c|c|c|}
\hline GENE & PROMOTER(S) & Epulopiscium \\
\hline \multicolumn{3}{|c|}{$\overline{\sigma^{A} \text { regulon }}$} \\
\hline \multicolumn{3}{|l|}{ jag } \\
\hline sigE & & $x$ \\
\hline soj & & $x$ \\
\hline spoOA & & $x$ \\
\hline spooJ & & $x$ \\
\hline spollE & & $x$ \\
\hline spol/GA & & $x$ \\
\hline spolllE & $\sigma^{\mathrm{A}}$ & $\mathrm{X}$ \\
\hline spolllJ & & $x$ \\
\hline \multicolumn{3}{|c|}{$\sigma^{H}$ regulon } \\
\hline sigF & & $x$ \\
\hline spollAA & & $x$ \\
\hline spollAB & & $x$ \\
\hline \multicolumn{3}{|c|}{$\sigma^{\mathrm{F}}$ regulon } \\
\hline dacF & $\sigma^{G}$ & $x$ \\
\hline$g p r$ & $\sigma^{G}$ & $x$ \\
\hline $\operatorname{lon} B$ & & $x$ \\
\hline $\operatorname{sig} G$ & $\sigma^{F}, \sigma^{G}$ & $x$ \\
\hline spollR & & $x$ \\
\hline spolvB & $\sigma^{F}, \sigma^{G}$ & $x$ \\
\hline spoVT & $\sigma^{G}$ & $x$ \\
\hline \multicolumn{3}{|l|}{ yhfw } \\
\hline \multicolumn{3}{|l|}{$y+f J$} \\
\hline yyac & & $x$ \\
\hline$\sigma^{\mathrm{E}}$ regulor & & \\
\hline
\end{tabular}

\begin{tabular}{|c|c|c|}
\hline \multicolumn{3}{|l|}{ bofA } \\
\hline $\cot B$ & & \\
\hline \multicolumn{3}{|l|}{$\operatorname{cotj} C$} \\
\hline CWID & $\sigma^{G}$ & $x$ \\
\hline$d a c B$ & & $x$ \\
\hline \multicolumn{3}{|l|}{$\operatorname{kamA}$} \\
\hline prkA & & $x$ \\
\hline sigk & & $x$ \\
\hline spmA & & $x$ \\
\hline$s p m B$ & & $x$ \\
\hline spollD & $\sigma^{E}$ & $x$ \\
\hline spollIAA & $\sigma^{E}$ & $x$ \\
\hline spolllAB & $\sigma^{\mathrm{E}}$ & $x$ \\
\hline spolllac & $\sigma^{E}$ & $x$ \\
\hline spoll/AD & $\sigma^{E}$ & $x$ \\
\hline spollIAE & $\sigma^{E}$ & $x$ \\
\hline spoll/AF & $\sigma^{E}$ & $x$ \\
\hline
\end{tabular}

Table 3 Genes conserved in Epulopiscium and C. lentocellum (Continued)

C. lentocellum

$\mathrm{X}$

$\mathrm{X}$

$\mathrm{X}$

$\mathrm{X}$

$\mathrm{X}$

$\mathrm{x}$

$\mathrm{X}$

$\mathrm{X}$

$\mathrm{X}$

$\mathrm{X}$

$x$

$x$

spollIAG

sPOIIIAH

spollID

spollP

spolva

spoVB

spovD

spoVE

spoVR

spsJ

yaat

yabP

yabe

yhbH

ylbJ

yngl

yqfC

yqfD

yagT

yaho

$y t v 1$

$\sigma^{G}$ regulon

gerkA

gerkB

gerkC

pdaA

$s p / B$

sPoVAA

spoVAB

spoVAC

SPOVAD

SPOVAEB

SPOVAF

$s s p B$

$\operatorname{ssp} C / F$

ybdM

ydfs

$\sigma^{\mathrm{K}}$ regulon

cots

SPoVFA

spoVFB

yabG

$y$ fnG

$\sigma^{E}$

$\sigma^{E}$

X

$\mathrm{x}$

$\mathrm{X}$

$x \quad x$

$\mathrm{X}$

$\mathrm{x}$

$\mathrm{x}$

$\mathrm{X}$

$\mathrm{x}$

$x$

$\mathrm{x}$

$\mathrm{X}$

$x$

$\mathrm{x}$

$\mathrm{x}$

$\mathrm{X}$

$\mathrm{X}$

$\mathrm{x}$

$\mathrm{x}$

$\mathrm{X}$

$\mathrm{x}$

$\mathrm{x}$

$x$

$x$

$x$

$\mathrm{X}$

$\mathrm{x}$

$x$

$\mathrm{x}$

$x$

$x$

$\mathrm{X}$

$\mathrm{X}$

$x$

$x$
$x$

$\mathrm{x}$

$\mathrm{X}$

$\mathrm{X}$

$\mathrm{X}$

$\mathrm{X}$

$\mathrm{X}$

X

$\mathrm{x}$

$\mathrm{x}$

X

$\mathrm{X}$

$\mathrm{X}$

X

$\mathrm{X}$

$\mathrm{X}$

$\mathrm{X}$

$\mathrm{X}$

$\mathrm{X}$

$\mathrm{X}$

$\mathrm{x}$

$\mathrm{X}$

$x$

$x$

$\begin{array}{cc}x & x \\ & x \\ x & x \\ x & x \\ x & x\end{array}$


Table 3 Genes conserved in Epulopiscium and C. lentocellum (Continued)

\begin{tabular}{ll}
\hline ygak & $\mathbf{x}$ \\
$y r k C$ & $\mathrm{x}$ \\
$\mathrm{ytcC}$ & $\mathrm{x}$ \\
$\mathrm{y} t / A$ & $\mathrm{x}$ \\
$\mathrm{yt} / \mathrm{C}$ & $\mathrm{x}$ \\
$\mathrm{y} t / D$ & $\mathrm{x}$ \\
\hline
\end{tabular}

activation of $\sigma^{\mathrm{G}}$ [45]. The gene coding for SpoIIQ is absent in clostridia [1] therefore involvement of SpoIIQ is a Bacillus-specific innovation that likely does not represent the ancestral mode of cell-cell communication used to trigger late forespore sigma factor activation.

Mechanisms to activate the late mother-cell sigma factor, $\sigma^{\mathrm{K}}$, are apparently the most specialized of the sporulation sigma factors. In B. subtilis, the gene encoding $\sigma^{\mathrm{K}}$ contains a $48 \mathrm{~kb}$ insertion sequence called the skin (sigma $\mathrm{K}$ intervening) element that must first be excised from the mother-cell chromosome by the recombinase SpoIVCA $[79,80]$. The reconstituted gene produces an inactive pro-protein which must be processed by SpoIVFB but BofA and SpoIVFA inhibit SpoIVFB activity [47,48]. These three proteins are transcribed by $\sigma^{\mathrm{E}}$ in the mother cell and localize to the outer forespore membrane. SpoIVB and CtpB, regulated by $\sigma^{\mathrm{G}}$ in the forespore, inhibit the actions of BofA and SpoIVFA allowing cleavage of pro- $\sigma^{\mathrm{K}}$ $[44,81]$. In this way, $\sigma^{\mathrm{K}}$ operates in the mother cell only after $\sigma^{\mathrm{G}}$ has been activated in the forespore. Only homologs for spoIVB and $\operatorname{ctp} B$ were found in Epulopiscium. Note that $\operatorname{ctp} B$ homologs are found in many non-spore-forming bacteria, which is why it is not included in the core list. The gene coding for SpoIVFA is absent in clostridia and although spoIVFB and bofA met the requirements to be included on the core list, neither is conserved in many clostridia and only bof $A$ was found in the $C$. lentocellum genome. The weak conservation of these proteins outside of the Bacilli indicates that the intricate mechanism of $\sigma^{\mathrm{K}}$ activation described in B. subtilis is a recent innovation.

In addition to conservation of sporulation sigma factors and many of the proteins responsible for regulating

\section{Phospho-acceptor domain}

B. subtilis

B. anthracis

C. acetobutylicum

C. botulinum

C. lentocellum Epulopiscium

\begin{abstract}
--MEKIKVCVADDNRELVSLLSEYIEGQEDMEVIGVAYNGOECLSLFKEKDPDVLVLDI IMPHLDGLAVLERLRESDLKKOPNVIMLTAFGOF ---MEKIKVCLVDDNKELVSMLESYVAAODDMEVI GTAYNGOECLNLLKDKOPDVLVLDI IMPHLDGLAVLEKMRHIERLROPSVIMLTAFGOE -MESRKISVLIADDNKEFCNILNDYLLNQSDMIVVGIAKDGVEALKL IENKKPDLVVLDI IMPRLDGLGVLEKLNNKDAENLPRI IVLSAVGQD -MEETKINVIIADDNKEFCNILSDYLLNQRDIMVTGIANDGVEALKLVEEKKPDLIILDIIMPHLDGLGVLEKLNSIDITPMPRVIVLSAVGQD -MFDQKMKILIADDNKDFSDI LMEF INRQEDMEVVNVAGNGEEACKLIQEVVPDIVILDVIMPYLDGIGVLERVDSMQLEKRPLFVMLSAVGQD METNKNIQIVIADDSKDMIDI LREFINKQAGLE IVGVAYDGNEAYDAVIKLAPDILILDVIMPNLDGISVLEKLKATKLSKKPIVIMLSAVGQD

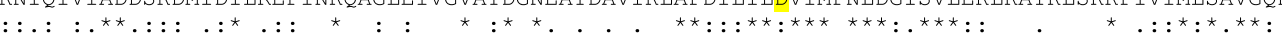

\section{Connector segment}

B. subtilis

B. anthracis

C. acetobutylicum

C. botulinum

C. lentocellum

Epulopiscium

DVTKKAVDLGASYFI LKPFDMENLVGHIRQVSGNASSVTHRAPSSQS-----------S I IRSSQPEPKKKNLDAS ITS I IHE I GVPAHIKGY DVTKKAVDLGASYFI LKPFDMENLTSHIROVSGKANATIKRPLPSF-------------RSATTVDGKPKNLDAS ITS I I HE I GVPAH I KGY KITQRAITLGADYYVVKPFDMDVFTNRIREMFNNTISNSEQKRSYQVEEKEASFAGTIANDVYSDNIGNKAVPLESEITS I I HQIGVPAH IKGY KITQRA INLGADYYVVKPFDMDVFTKRIRQMFN NTI S SEEVRRPVVMPETCSQE-------KISLSKNEPA LEEQE ITDI I HE I GVPAH I KGY KITERALALGAEYYIVKPFDMETLVNRIRQLKN MALSS SNASKNSTST------LTSSRQLLPKSKGMPTAH SLETEVTSVIHEIGVPAHIKGY KITGRALALGAEYYIVKPFDLDALVLRIKQLMNMQDMYNMPQNQNL----------IKEDNKEEKERISKFTLETEVTS I IHEIGIPAHIKGY .:* $:^{\star}: \star \star \star *{ }^{\star}:::^{\star \star \star \star}::::^{\star}:::$

\section{Effector domain}

B. subtilis

C. acetobutylicum

C. botulinum

C. lentocellum

Epulopiscium
B. anthracis

LYLREAISMVYNDIELLGSITKVLYPDIAKKFNTTASRVERAIRHAIEVAWSRGNIDS ISSLFGYTVSMTKAKPTNSEFIAMVADKLRLEHKAS MYLREA I SMVYNDIELLGS ITKVLYPDIAKKYNTTASRVERA IRHAIEVAWSRGNIDS ISSLFGYTVSMSKAKPTNSEF IAMVADKLRLEHKAS MYLREAITMVVNNMELLSAVTKELYPS IAKKYNTTASRVERAIRHAIEVAWSRGQVETINKLFGYTINNGKGKPTNSEFIAMIADKLRLKNKVS MYLREAITMVVNDMELLSAVTKELYPS IAKKYNTTASRVERAIRHAIEVAWSRGQVETINNIFGYTINNGKGKPTNSEFIAMVADKLRLKNRVC QYLRDA I IMVINDME I LNS ITKQLYPNIAKQYNTTPSRVERAIRHAIEVAWSRGKMDTIDKLFGYTVNNGKGKPTNSEFIALIADRLRLEMQVG QYLRDAI IMAINDMDILNSITKOLYPS IAKRYNTTPSRVERAIRHAIEVAWSRGKMETLEKLFGYTVNNGKGKPTNSEFVALIADKLRLOMOVS

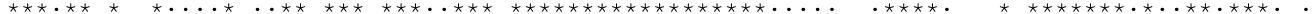

\section{$\mathrm{H} \quad \mathrm{T} \quad \mathrm{H}$}

Figure 2 An alignment of Spo0A homologs. The predicted amino acid sequences of Spo0A from B. subtilis 168, B. anthracis Ames, C. acetobutylicum ATCC 824, C. botulinum ATCC 3502, Cellulosilyticum lentocellum DSM 5427 and Epulopiscium sp. type B were aligned using CLUSTAL $\Omega$. The conserved phosphorylation site (highlighted in yellow), the conformational switch (in green) and the DNA recognition helix (light blue) are found in all homologs. The connector segment (outlined in black) links the upstream phospho-acceptor and downstream effector domains. Shaded bars below the effector domain indicate the helix-turn-helix (HTH) DNA binding motif. 


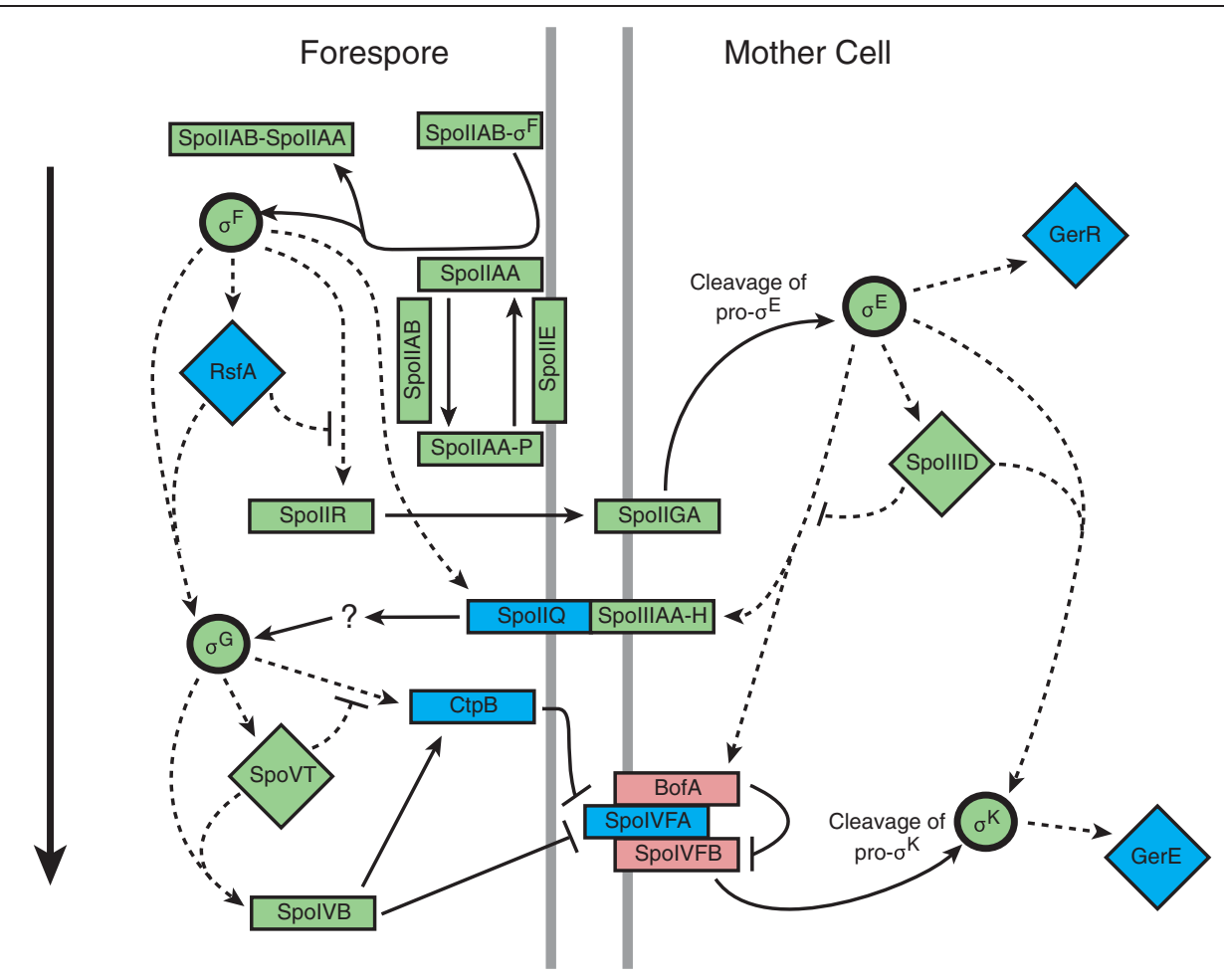

Figure 3 Conservation of the B. subtilis sporulation regulatory cascade in Epulopiscium sp. type B. Sporulation-specific sigma factors (circles), associated transcription factors (diamonds) and other signal transduction or regulatory proteins involved in sigma activation (rectangles) are shown. Colors of the proteins indicate the gene presence in Epulopiscium (green), on the core list but not in Epulopiscium (red), and absence from the core list (blue). Control of gene expression is indicated by dotted lines and arrows. Signaling pathways and other protein interactions are denoted with solid lines and arrows. Temporal transcriptional progression through the cascade is shown by the position on the diagram with earlier stages near the top. A detailed explanation of the regulatory cascade as it occurs in B. subtilis is provided in the text. Figure is adapted from de Hoon et al. (2010).

their activation, we found homologs of transcription factors SpoIIID and SpoVT. These proteins work together with their associated sigma factor $\left(\sigma^{\mathrm{E}}\right.$ and $\sigma^{\mathrm{G}}$, respectively) to modulate transcription of genes downstream in the process. Other transcription factors that function during sporulation in B. subtilis (RsfA, GerR and GerE) are not conserved in the clostridia. These feed-forward loops appear to be a Bacilli-specific amendment. Based on these results, we conclude that gene regulation by sporulation-specific sigma factors and their associated transcription factors is highly conserved in Epulopiscium. With the exception of bofA, all of the core sporulation genes coding for components of the central regulatory cascade that are conserved in the C. lentocellum genome are also conserved in Epulopiscium.

\section{Engulfment genes are highly conserved in Epulopiscium}

SpoIID, SpoIIP and SpoIIM are required for degradation of septal peptidoglycan and progression toward forespore engulfment in B. subtilis [21]. We found Epulopiscium genes that code for homologs of SpoIID and SpoIIP but could not identify a SpoIIM homolog. SpoIIM appears highly conserved in spore-forming bacteria but is curiously absent from the Lachnospiraceae, as the genome of C. lentocellum also lacks an apparent homolog of spoIIM (Table 3). The Epulopiscium spoIIP initially retrieved from the pseudomolecule did not meet the requirements to be considered a homolog in this analysis, as it appeared to be missing its $5^{\prime}$ end. In B. subtilis, spoIIP has its own $\sigma^{\mathrm{E}}$ promoter [82] but is also the second gene in an operon with gpr [63], and this operon structure is widely conserved in Bacillus and Clostridium spp. A truncated gpr homolog was identified in the Epulopiscium draft genome. Based on this information, PCR and sequence analysis was used to recover the complete Epulopiscium gpr - spoIIP operon.

Other proteins that function during engulfment in $B$. subtilis are SpoIIB, SpoIIIE, SpoIIIAH and SpoIIQ. SpoIIB likely plays a role in the localization of the SpoIIDMP complex in B. subtilis [20] but it is not conserved in the clostridia. Null mutants of spoIIB in B. subtilis are oligosporogenous, and this sporulation defect becomes more pronounced when combined with a spoVG mutation [83]. In addition to its DNA translocase activity, SpoIIIE has been implicated in the fusion of the leading edge of the mother-cell membrane after 
migrating around the forespore [84,85]. We identified homologs of SpoIIIE in both Epulopiscium and C. lentocellum. Beyond the role of the SpoIIIAH - SpoIIQ complex in $\sigma^{\mathrm{G}}$ activation, these two proteins may perform an important role during engulfment. It has been suggested that as the mother-cell membrane migrates around the forespore, these proteins bind to one another near the leading edge of the mother-cell membrane to prevent it from retreating back toward the midcell [22]. Homologs of the spoIIIA operon were identified in C. lentocellum and Epulopiscium. With the exception of SpoIIM and SpoIIQ, all of the known proteins required for engulfment in B. subtilis are coded for in the Epulopiscium genome (Figure 4). Neither SpoIIM nor SpoIIQ are coded for in the $C$. lentocellum genome.

\section{Late stage sporulation proteins in the Epulopiscium genome}

A small number of late sporulation genes were identified in the Epulopiscium sp. type B genome. This may be an underestimate as many of the proteins in this category are very small and functionally redundant. For example, it is possible that some coat proteins have diverged to a degree that they could not to be detected by our methods. Regardless, B. subtilis uses more than 75 proteins for cortex and coat formation, spore maturation and germination of which Epulopiscium has retained 17 possible homologs. In comparison, the C. lentocellum genome has 31. The genes retained in Epulopiscium may perform novel functions, or are relics of its spore-forming ancestry. Previous studies have identified sporulation homologs in the genomes of non-sporulating members of the Firmicutes [2]. Additionally, many surgeonfish intestinal symbionts that are close relatives of Epulopiscium sp. type B form endospores [12], and would likely need late sporulation proteins similar to those in B. subtilis and the clostridia for the formation of cortex and coat as well as spore maturation and germination.

Based on their functions in B. subtilis, we classified the late sporulation genes located in C. lentocellum and/or Epulopiscium. With the notable exception of genes coding for SASPs $(s s p B, s s p C / F)$ or SASP degradation $(g p r)$, genes involved in resistance properties of a mature spore and germination signal receptors (gerK operon) are more highly conserved in C. lentocellum. Specifically, C. lentocellum has the nine genes required for the synthesis and forespore-uptake of dipicolinic acid (DPA) while Epulopiscium has only one of these genes. Likewise, only $C$. lentocellum has $s p l B$, which codes for the DNA repair enzyme spore-photoproduct lyase. Surprisingly, all of the ten genes on the list involved in cortex biosynthesis or other cortex-associated properties that are conserved in C. lentocellum are also found in Epulopiscium. In addition, spoIVA, yabP and yabQ, which encode scaffolding proteins important for cortex and coat morphogenesis [86-88], were found in both C. lentocellum and Epulopiscium. We speculate that the synthesis of a cortex-like peptidoglycan may accommodate several Epulopiscium characteristics including rapid offspring growth, emergence of offspring from the mother cell or other functions that support a large bacterial cell. Four coat protein genes were found in C. lentocellum but only one of these appears conserved in Epulopiscium. The biased distribution of functional categories represented in Epulopiscium suggests that cortex biosynthetic machinery has been retained, as well as the DNA-protective SASPs, and these proteins may still serve some function. Overall, the pattern of conserved genes in C. lentocellum compared with Epulopiscium (Figure 5) supports our hypothesis that there is a strong selection to retain early stage sporulation gene homologs in Epulopiscium such as those necessary for compartmentalized gene expression, engulfment and developmental progression.

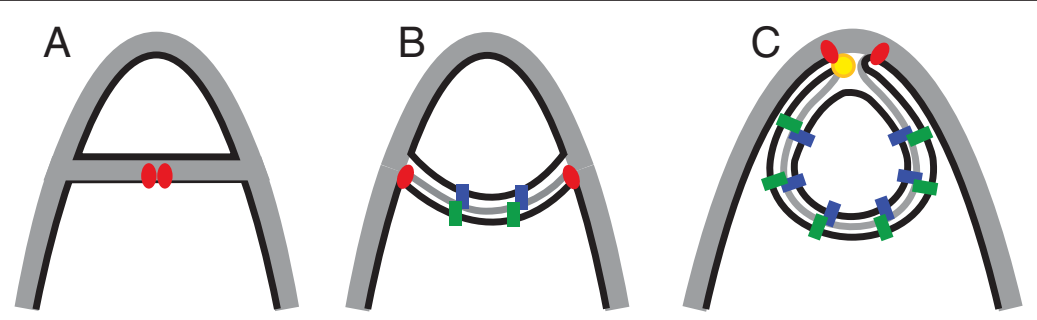

Figure 4 Epulopiscium engulfment model. The Epulopiscium genome codes for all of the genes known to be essential for engulfment in $B$. subtilis, except spollM and spol/Q which are also absent in C. lentocellum. A) SpollD and SpollP assemble into a complex (red ovals) at the division septum and degrade the septal peptidoglycan. B) As the mother-cell membrane wraps around the offspring, the IIDP complex tracks along the leading edge where it is involved in interactions with the mother-cell peptidoglycan and synthesis of offspring cell wall. C) When it reaches the cell tip, membrane fusion is mediated by SpollIE (yellow circle). During engulfment, SpollIAH (green rectangles) produced in the mother cell and a hypothetical protein (blue rectangles) from the offspring cell bind and prevent backward movement of the mother-cell membrane. In this diagram, black lines indicate membranes and grey peptidoglycan. 


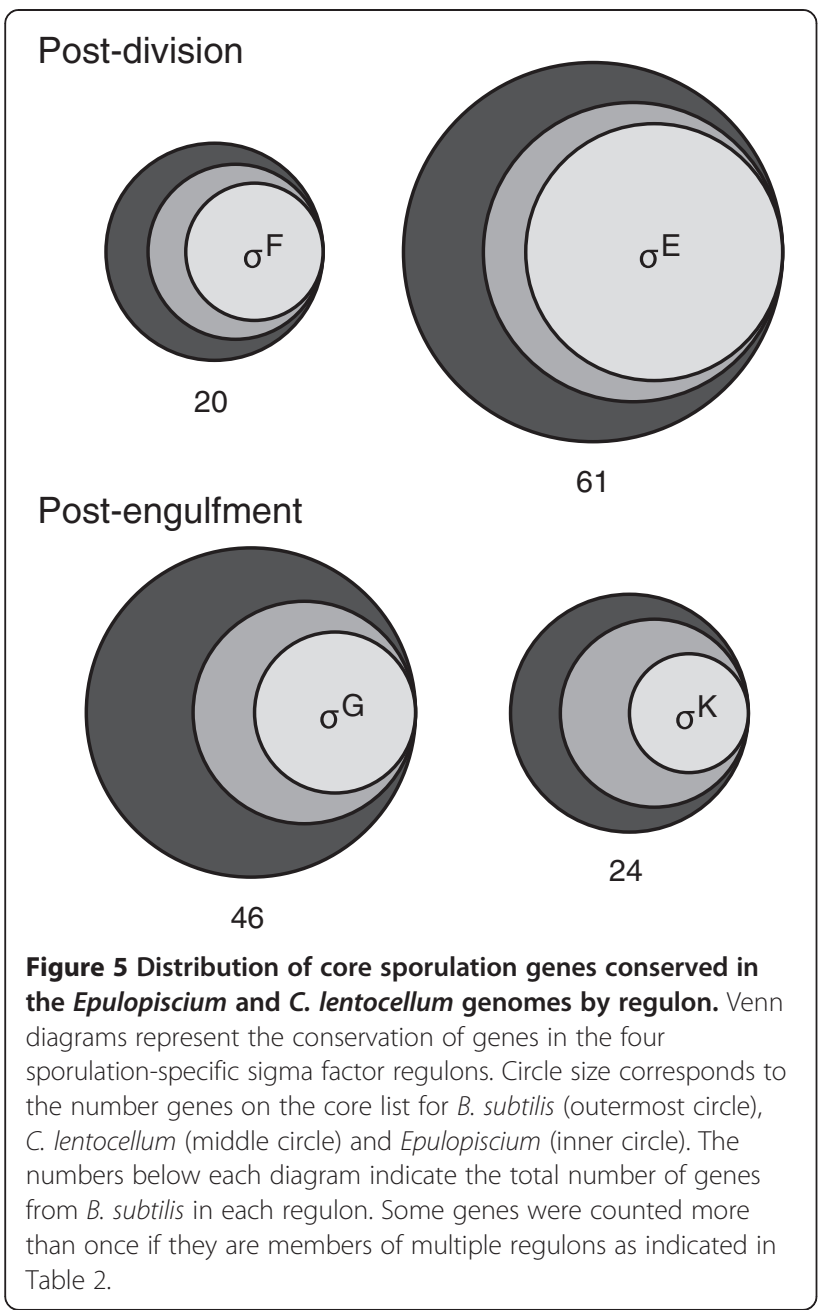

\section{Promoter analysis of putative developmentally regulated genes}

For each of the sporulation genes found in the Epulopiscium genome, the region immediately upstream of the predicted start codon ( $300 \mathrm{bp})$ was visually scanned for potential promoter sequences (Table 4 ). While this analysis is not definitive, we reasoned that identifiable promoters that match their predicted B. subtilis counterparts would reinforce the predictions placing genes in particular regulons. Consensus of the -10 and -35 promoter sequences from $B$. subtilis promoters were used $[53,63,89]$. We were able to identify $\sigma^{\mathrm{F}}$ promoters upstream of sigG and $s p o I V B$, and $\sigma^{\mathrm{E}}$ promoters upstream of spoIID, the spoIIIA operon, spoIIID, the yabPQ operon and the $y q f C D$ operon. $\sigma^{\mathrm{G}}$ promoters were found upstream of dacF, cwlD, sigG, spoIVB, spoVT and the gpr - spoIIP operon. Only one gene, spoVFB, was found to have a $\sigma^{\mathrm{K}}$ promoter. Our analysis of the putative $d a c F$ homolog indicated that approximately $50 \%$ of the $5^{\prime}$ end of the gene was present in the pseudomolecule, however, we were unable to obtain a full-length gene by PCR. The gene spoVFB codes for the $ß$-subunit of DPA synthase and is usually located in a bicistonic operon downstream of spoVFA, the gene for the $\alpha$-subunit of the DPA synthase [90]. DPA is found in abundance only in mature endospores [91] and is a distinct feature of the phasebright spores of the Epulopiscium-like symbionts of Naso lituratus [12]. Although we were unable to recover spoVFA from Epulopiscium, we did find homologs of spoVFA and spoVFB adjacent to each other in the C. lentocellum genome.

\section{Conclusions}

The comparative analysis of the draft Epulopiscium sp. type B genome with the complete C. lentocellum genome substantiates our hypothesis that the production of intracellular offspring in Epulopiscium evolved from endospore formation. All of the genes identified in $C$. lentocellum that function in engulfment as well as the core transcriptional regulatory cascade, and the associated intracellular communication network that coordinates sigma factor activation, were found in the Epulopiscium genome. While we could identify homologs of late sporulation genes, a large proportion of these were not recovered from Epulopiscium. Since we used a draft genome to explore the conservation of sporulation genes in Epulopiscium, it is possible that we did not recover all of the sporulation genes retained in this genome, however, we would not expect a functional bias in the distribution of genes recovered. Therefore the fewer late genes recovered in Epulopiscium probably reflect the reduction of this class of genes in the evolution of its genome.

Although Epulopiscium sp. type B is closely related to surgeonfish intestinal symbionts that form multiple endospores to reproduce [12], it appears that type B cells may no longer have the genetic capacity to form a dormant and fully resistant endospore. Many intestinal anaerobes, from harmful pathogens to benign commensals, use endospores for effective dispersal between vertebrate hosts $[8,10,92]$. The ability of an intestinal bacterium to produce an endospore should be valuable to survival. Why then would Epulopiscium sp. type B lose this trait? We speculate that the perpetuation of large cell size and the ability to maintain a longer residence in an individual host may be factors that contributed to the loss of dormancy and associated resistance traits in offspring development in this lineage. The large size of Epulopiscium sp. type B cells may be important to maintain their position in the gut and to avoid predation by the ciliate predators that cohabitate the N. tonganus intestinal tract [61]. The growth and development of offspring within a metabolically active mother cell may be essential for maintaining these benefits throughout the life cycle of an individual. It is also possible that the 
Table 4 Promoters found upstream of sporulation gene homologs in the Epulopiscium genome

\begin{tabular}{|c|c|c|c|c|c|c|c|c|}
\hline \multirow[t]{3}{*}{ GENE/OPERON } & \multicolumn{8}{|c|}{ PROMOTER } \\
\hline & \multicolumn{2}{|r|}{$\sigma^{\mathrm{F}}$} & \multicolumn{2}{|c|}{$\sigma^{\mathrm{E}}$} & \multicolumn{2}{|c|}{$\sigma^{G}$} & \multicolumn{2}{|r|}{$\sigma^{\mathrm{K}}$} \\
\hline & -35 & -10 & -35 & -10 & -35 & -10 & -35 & -10 \\
\hline $\operatorname{sig} G$ & GTATA & GGGTATCCTA & & & GTATA & TATCCTA & & \\
\hline spolvB & GTATA & GGCAATTTTA & & & GTATA & AATाTA & & \\
\hline spollD & & & TTATAAGT & TCATATAATT & & & & \\
\hline spolllA & & & TAATGATT & GCATATACTG & & & & \\
\hline spolllD & & & TAATATAT & GCATATTATT & & & & \\
\hline spolva & & & TCATATCC & ACATATAGTT & & & & \\
\hline yabPQ & & & GAATAATT & AAATATAAAT & & & & \\
\hline yqfCD & & & GAATACTT & GCATAATATG & & & & \\
\hline dacF & & & & & GTATA & AATAATA & & \\
\hline CWID & & & & & GAATT & GATAATA & & \\
\hline gpr-spollP & & & & & GATTA & TATATTA & & \\
\hline spovt & & & & & GCATA & CATAATA & & \\
\hline SpoVFB & & & & & & & TCACA & TCATATTATA \\
\hline B. subtilis consensus ${ }^{a}$ & GTATA & GGNAANAMTR & TYATATIT & KCATANANTN & GNATA & CAWAMTA & KCACM & GCATANNNTA \\
\hline
\end{tabular}

${ }^{a}$ Consensus sequences from $B$. subtilis were based on Wang et al. (2006) and Eichenberger et al. (2004). Bold indicates a highly conserved base. $\mathrm{N}=\mathrm{A}, \mathrm{T}, \mathrm{G}, \mathrm{C}$; $\mathrm{R}=\mathrm{A}, \mathrm{G} ; \mathrm{Y}=\mathrm{C}, \mathrm{T} ; \mathrm{K}=\mathrm{T}, \mathrm{G} ; \mathrm{M}=\mathrm{A}, \mathrm{C} ; \mathrm{W}=\mathrm{A}, \mathrm{T}$.

manifestation of some resistance traits may simply be impossible for a cell as large as an Epulopiscium sp. type B offspring. For example, the formation of a flawless spore coat may be physically impossible for this size of cell.

In the study outlined here, we generated the first genome sequence for any Epulopiscium species and use it to provide insight into the evolution of a novel form of cellular reproduction in the Epulopiscium lineage. Based on its phylogenetic position among endospore-forming lineages, we reason that formation of active intracellular offspring in Epulopiscium sp. type B is a recent modification of the sporulation program. Given the number of sporulation gene homologs found in the Epulopiscium genome, we consider it highly unlikely that the developmental program was assembled through multiple horizontal transfer events. Our comparative study reveals that genes essential for physical (e.g. engulfment of the offspring cell) and regulatory mechanisms (e.g. alternative sigma factors and intracellular communication) have been maintained in a live-offspring-bearing cell. We also found that genes involved in the synthesis of a modified form of peptidoglycan have been conserved. These may be important for offspring growth and intracellular development. Clearly further functional studies are required to test the above models and identify additional mechanisms acquired or modified during evolution of offspring formation in Epulopiscium. The findings presented here will provide a framework to begin to assess genetic programs expressed during development in Epulopiscium.

\section{Methods}

\section{Epulopiscium sample collection and DNA extraction}

Naso tonganus were collected by spear on outer reefs in the vicinity of Lizard Island, Great Barrier Reef, Australia. Sections of the gut were removed and the contents were fixed in $80 \%$ ethanol. Samples were stored at $-20^{\circ}$ $\mathrm{C}$ upon arrival at the laboratory.

Epulopiscium cells were manually selected from fixed intestinal contents, using a standard Gilson pipettor and a Nikon SMZ-U dissecting microscope. Cell lysis and DNA extraction were performed as previously described [61]. Briefly, Epulopiscium type B cells were incubated with $100 \mu \mathrm{g} / \mathrm{ml}$ Proteinase $\mathrm{K}$ for one hour at $50{ }^{\circ} \mathrm{C}$. DNA was extracted with phenol:chloroform and precipitated. After rinsing with $70 \%$ ethanol, the DNA was resuspended in TE (10 mM Tris, $1 \mathrm{mM}$ EDTA, pH 8) buffer.

\section{Genome sequencing and analysis}

A draft genome sequence was generated using a random shotgun approach and paired-end Sanger sequencing. Sequence reads, providing approximately 8-fold coverage of the estimated $4 \mathrm{Mbp}$ genome were assembled using a combination of the Celera Assembler [93] and TIGR Assembler [94]. To improve assembly, reads were first sorted based on $\mathrm{G}+\mathrm{C}$ content and only reads that had 23 - 53\% G $+\mathrm{C}$ were retained. The resulting reads were assembled again and open reading frames (ORFs) predicted using GLIMMER [95]. A BLAST [96] analysis of predicted ORFs against the National Center for Biotechnological Information (NCBI) non-redundant protein (nr) 
database was used to remove non-bacterial sequences. This strategy yielded 92 large contigs $12 \mathrm{~kb}$ to $119 \mathrm{~kb}$ in length. These contigs are deposited in GenBank under the accession number NZ_ABEQ01000000.

Draft genome assessment of the 92 large contigs was performed using two approaches. First, the total number of rRNA and tRNA genes were predicted using RNAmmer [97] and tRNAscan-SE [98], respectively. This analysis was also performed on the small contigs and singletons in the Epulopiscium draft genome. Second, a clusters of orthologous genes (COG) analysis [99] was performed using the Epulopiscium predicted proteome. Each protein was compared against a local COG database obtained from NCBI (ftp://ftp.ncbi.nih.gov/pub/ $\mathrm{mmdb} / \mathrm{cdd} /$, accessed: 06/23/2011) using RPSBLAST [100] and the total number of proteins in each COG category was tabulated and represented as a percent of the number of COG-annotated proteins in the genome. This analysis was also performed for all sequenced genomes belonging to the phylum Firmicutes and genus Clostridium using the complete sequenced microbial genome collection from the NCBI (http://www.ncbi.nlm.nih.gov/ genomes/lproks.cgi, accessed: 06/23/2011).

\section{Generation of a core sporulation gene list}

An initial list of sporulation genes was created based on four studies describing the regulons of the four sporulation-specific sigma factors and the transcription factor Spo0A from B. subtilis $[29,53,63,64]$. Other genes reported in the GenoList Comparative Microbial Genome Browser [65] with putative sporulation functions in $B$. subtilis 168 were added to this list. Any gene coding for a protein with a known vegetative growth function was removed. This list was refined further by BLASTP (http:// blast.ncbi.nlm.nih.gov/Blast.cgi) searches to determine the distribution of similar proteins in the NCBI nr database. Multiple searches were performed and limited to the phylum Firmicutes, class Clostridia, and if necessary Clostridium spp. and Bacillus spp. Proteins represented in 15 strains of endospore-forming bacteria in both class Bacilli and class Clostridia with greater than or equal to $70 \%$ query coverage and $20 \%$ identity were retained on the list. Proteins with top hits for putative homologs in two or more species within the non-spore-forming genera Listeria, Streptococcus, Lactobacillus, Staphylococcus, Enterococcus, and Peptostreptococcus, indicating a vegetative function, were removed. Several key proteins that were first identified as essential to sporulation (Spo0A, Spo0J, Soj, SpoIIIE and SpoIII) were added back to the list.

\section{Search for core proteins coded for in the Epulopiscium} and $C$. lentocellum genomes

All contigs and well-represented single reads from the Epulopiscium sp. type B draft genome were concatenated to form a pseudomolecule. Coordinates for all junctions between contigs and single reads were entered into an Excel file for easy reference. The pseudomolecule and the complete C. lentocellum DSM 5427 genome [62] were searched for homologs of core proteins using TBLASTN and BLASTP, respectively. For each query, the top hits in the Epulopiscium or C. lentocellum genome were compared to Bacillus and Clostridium sequences in the NCBI $\mathrm{nr}$ database using BLASTP. If reverse-BLAST searches recovered a top hit that was different from the $B$. subtilis core protein used in the initial BLAST analysis, the protein was eliminated from the list. By this method, additional putative homologs with weak hits (below the original cutoff values) were identified. Operon structure was an additional criterion used to identify homologs. Core sporulation protein homologs identified in C. lentocellum were then used to search the Epulopiscium genome using TBLASTN. Multiple sequence alignments were performed using Clustal $\Omega$ [101].

\section{Confirmation of dacF, gpr-spollP, spoVT, sspC/F, ybdM and yyaC}

Primers were developed to amplify sporulation genes identified in the Epulopiscium genome that were located in small contigs or singletons or to link genes in operons predicted from synteny in the genomes of other spore formers (Table 5). PCR was performed using standard reaction conditions, and products were cloned into the pCR 2.1 TOPO vector (Invitrogen) following the protocol provided by the manufacturer. Sequences of the

\begin{tabular}{|c|c|}
\hline DESIGNATION & SEQUENCE (5' TO 3') \\
\hline GprendF & ATAGACGCATTAGGAGCACG \\
\hline SpollPbegR & GCTTAGCGGACTTTGTATCACC \\
\hline EpuloGprF & GAGAACATTGGTATTACAGGCG \\
\hline EpuloGprR & GCTTGCATATATCACCTCCTTG \\
\hline EpuloSpollPF & CATTGCTGTTCACCCAGGTA \\
\hline EpuloSpollP859R & GCAGTAACCTTAGACGCA \\
\hline EpuloSpollP684F & CAAAGTATGGGCTAAATGTATTGC \\
\hline EpuloSpollPR & CAAAACAACAGACATCACCG \\
\hline EpuloDacFF & GAGCCCCTGATTGTAACATTT \\
\hline EpuloDacFR1 & GGTTAATCCAAATTCACTTTCGCC \\
\hline EpuloSpoVTF & TTAGTATTATCAAGAGAAAAACAGCAT \\
\hline EpuloSpoVTR & TGAACATTTGTCAAGATATAAATGCAA \\
\hline EpuloSspC/FF & CTCCAAAATAATTTAGGAATATTGTCC \\
\hline EpuloSspC/FR & TACACAGAAGTACCCCTTTGC \\
\hline EpuloYbdMF & GAGTGGTTCTITTAGTGGCTCTG \\
\hline EpuloYbdMR & AACATGACCTCACACTGGCA \\
\hline EpuloYyaCF & GCGGTGTTTGTGTAAGTGC \\
\hline EpuloYyaCR & TACACCCGAAGAATTAAGCA \\
\hline
\end{tabular}


clones were determined using Big Dye Terminator chemistry and an Applied Biosystems Automated 3730 DNA analyzer, performed at the Cornell Life Sciences Core Laboratories Center and analyzed with Geneious Pro 5.4.2 (Biomatters). The sequences for the gpr-spoIIP operon [accession number JN402987], dacF [JN402985], spoVT [JN402986], sspC/F [JN402984], $y b d M$ [JN402982], and yyaC [JN402983] are available from GenBank.

\section{Competing interests}

The author(s) declare that they have no competing interests.

\section{Acknowledgements}

We thank the staff and directors of the Lizard Island Research Station and Howard Choat for advice and assistance in the field. We also thank lan Hewson for advice with batch BLAST analyses and John Helmann for help with promoter identification and analysis, and three anonymous reviewers for their comments and suggestions. This research was funded by the National Science Foundation grant 0721583. Collections were carried out under GBRMPA Permit number G03/3871.1 and James Cook University Ethics Approval No. A503.

\section{Author details}

'Department of Microbiology, Cornell University, Ithaca, NY 14853, USA. ${ }^{2}$ Department of Bacteriology, University of Wisconsin-Madison, Madison, WI 53706, USA. ${ }^{3}$ School of Biological Sciences, University of Auckland, Auckland 1142, New Zealand.

\section{Authors' contributions}

ERA and DAM designed the study and wrote the initial manuscript draft. KDC and ERA collected samples. DAM and GS designed and performed the computational analyses. DAM and ERA interpreted results. All authors contributed to writing the manuscript and approved the final draft.

Received: 3 December 2011 Accepted: 21 June 2012

Published: 21 June 2012

\section{References}

1. de Hoon MJ, Eichenberger P, Vitkup D: Hierarchical evolution of the bacterial sporulation network. Curr Biol 2010, 20(17):R735-R745.

2. Onyenwoke RU, Brill JA, Farahi K, Wiegel J: Sporulation genes in members of the low $\mathrm{G}+\mathrm{C}$ Gram-type-positive phylogenetic branch (Firmicutes). Arch Microbiol 2004, 182(2-3):182-192.

3. Nicholson WL, Munakata N, Horneck G, Melosh HJ, Setlow P: Resistance of Bacillus endospores to extreme terrestrial and extraterrestrial environments. Microbiol Mol Biol Rev 2000, 64(3):548-572.

4. Setlow P: I will survive: DNA protection in bacterial spores. Trends Microbiol 2007, 15(4):172-180

5. Angert ER: Alternatives to binary fission in bacteria. Nat Rev Microbiol 2005, 3(3):214-224

6. Smith LD: Clostridium oceanicum, sp. n., a sporeforming anaerobe isolated from marine sediments. J Bacteriol 1970, 103(3):811-813.

7. Klaasen HL, Koopman JP, Van den Brink ME, Bakker MH, Poelma FG, Beynen AC: Intestinal, segmented, filamentous bacteria in a wide range of vertebrate species. Lab Anim 1993, 27(2):141-150.

8. Chase DG, Erlandsen SL: Evidence for a complex life cycle and endospore formation in the attached, filamentous, segmented bacterium from murine ileum. J Bacteriol 1976, 127(1):572-583.

9. Robinow CF: Observations on the structure of Bacillus spores. J Gen Microbiol 1951, 5(3):439-457.

10. Angert ER, Losick RM: Propagation by sporulation in the guinea pig symbiont Metabacterium polyspora. Proc Natl Acad Sci U S A 1998, 95(17):10218-10223.

11. Clements KD, Sutton DC, Choat JH: Occurrence and characteristics of unusual protistan symbionts from surgeonfishes (Acanthuridae) of the Great Barrier Reef, Australia. Marine Biol 1989, 102:403-412.
12. Flint JF, Drzymalski D, Montgomery WL, Southam G, Angert ER: Nocturnal production of endospores in natural populations of Epulopiscium-like surgeonfish symbionts. J Bacteriol 2005, 187(21):7460-7470.

13. Angert ER, Brooks AE, Pace NR: Phylogenetic analysis of Metabacterium polyspora: clues to the evolutionary origin of daughter cell production in Epulopiscium species, the largest bacteria. J Bacterio/ 1996, 178(5):1451-1456.

14. Ryter A: Etude morphologique de la sporulation de Bacillus subtilis. Ann Inst Pasteur 1965, 108:40-60.

15. Kay D, Warren SC: Sporulation in Bacillus subtilis. Morphological changes. Biochem J 1968, 109(5):819-824.

16. Fitz-James PC, Young IE: Morphology of sporulation. In The bacterial spore. Edited by Gould GW, Hurst A. New York, N.Y: Academic; 1969:39-72.

17. Bylund JE, Haines MA, Piggot PJ, Higgins ML: Axial filament formation in Bacillus subtilis: induction of nucleoids of increasing length after addition of chloramphenicol to exponential-phase cultures approaching stationary phase. J Bacteriol 1993, 175(7):1886-1890.

18. Wu L, Errington J: Bacillus subtilis SpolllE protein required for DNA segregation during asymmetric cell division. Science 1994, 264(5158):572-575.

19. Bath J, Wu L, Errington J, Wang JC: Role of Bacillus subtilis SpolllE in DNA transport across the mother cell-prespore division septum. Science 2000, 290(5493):995-997.

20. Aung S, Shum J, Abanes-De Mello A, Broder DH, Fredlund-Gutierrez J, Chiba S, Pogliano K: Dual localization pathways for the engulfment proteins during Bacillus subtilis sporulation. Mol Microbiol 2007, 65(6):1534-1546.

21. Chastanet A, Losick R: Engulfment during sporulation in Bacillus subtilis is governed by a multi-protein complex containing tandemly acting autolysins. Mol Microbiol 2007, 64(1):139-152.

22. Broder DH, Pogliano K: Forespore engulfment mediated by a ratchet-like mechanism. Cell 2006, 126(5):917-928.

23. Ellar DJ: Spore specific structures and their function. Symp Soc Gen Microbiol 1978, 28:295-325.

24. Henriques AO, Moran CP Jr: Structure and assembly of the bacterial endospore coat. Methods 2000, 20(1):95-110.

25. Burbulys $D$, Trach KA, Hoch JA: Initiation of sporulation in B. subtilis is controlled by a multicomponent phosphorelay. Cell 1991, 64(3):545-552.

26. Fujita M, Losick R: Evidence that entry into sporulation in Bacillus subtilis is governed by a gradual increase in the level and activity of the master regulator Spo0A. Genes Dev 2005, 19(18):2236-2244.

27. Veening JW, Hamoen LW, Kuipers OP: Phosphatases modulate the bistable sporulation gene expression pattern in Bacillus subtilis. Mol Microbiol 2005, 56(6):1481-1494.

28. Lopez D, Kolter R: Extracellular signals that define distinct and coexisting cell fates in Bacillus subtilis. FEMS Microbiol Rev 2010, 34(2):134-149.

29. Molle V, Fujita M, Jensen ST, Eichenberger P, Gonzalez-Pastor JE, Liu JS, Losick R: The Spo0A regulon of Bacillus subtilis. Mol Microbiol 2003, 50 (5):1683-1701.

30. Losick R, Stragier P: Crisscross regulation of cell-type-specific gene expression during development in B. subtilis. Nature 1992 . 355(6361):601-604.

31. Hilbert DW, Piggot PJ: Compartmentalization of gene expression during Bacillus subtilis spore formation. Microbiol Mol Biol Rev 2004, 68(2):234-262.

32. Gholamhoseinian A, Piggot PJ: Timing of spoll gene expression relative to septum formation during sporulation of Bacillus subtilis. J Bacteriol 1989, 171(10):5747-5749.

33. Duncan L, Losick R: SpollAB is an anti-sigma factor that binds to and inhibits transcription by regulatory protein $\sigma^{F}$ from Bacillus subtilis. Proc Natl Acad Sci U S A 1993, 90(6):2325-2329.

34. LaBell TL, Trempy JE, Haldenwang WG: Sporulation-specific sigma factor $\sigma^{29}$ of Bacillus subtilis is synthesized from a precursor protein, $\mathrm{P}^{31}$. Proc Natl Acad Sci U S A 1987, 84(7):1784-1788.

35. Duncan L, Alper S, Losick R: SpollAA governs the release of the cell-type specific transcription factor $\sigma^{F}$ from its anti-sigma factor SpollAB. J Mol Biol 1996, 260(2):147-164.

36. Clarkson J, Campbell ID, Yudkin MD: Physical evidence for the induced release of the Bacillus subtilis transcription factor, $\sigma^{F}$, from its inhibitory complex. J Mol Biol 2004, 340(2):203-209.

37. Arigoni F, Duncan L, Alper S, Losick R, Stragier P: SpollE governs the phosphorylation state of a protein regulating transcription factor $\sigma^{F}$ 
during sporulation in Bacillus subtilis. Proc Natl Acad Sci U S A 1996, 93 (8):3238-3242.

38. Karow ML, Glaser P, Piggot PJ: Identification of a gene, spollR, that links the activation of $\sigma^{\mathrm{E}}$ to the transcriptional activity of $\sigma^{\mathrm{F}}$ during sporulation in Bacillus subtilis. Proc Natl Acad Sci U S A 1995, 92(6):2012-2016.

39. Hofmeister AE, Londono-Vallejo A, Harry E, Stragier P, Losick R: Extracellular signal protein triggering the proteolytic activation of a developmental transcription factor in B. subtilis. Cell 1995, 83(2):219-226.

40. Jonas RM, Weaver EA, Kenney TJ, Moran CP Jr, Haldenwang WG: The Bacillus subtilis spollG operon encodes both $\sigma^{\mathrm{E}}$ and a gene necessary for $\sigma^{\mathrm{E}}$ activation. J Bacteriol 1988, 170(2):507-511.

41. Errington J, Appleby L, Daniel RA, Goodfellow H, Partridge SR, Yudkin MD: Structure and function of the spolllJ gene of Bacillus subtilis: a vegetatively expressed gene that is essential for $\sigma^{G}$ activity at an intermediate stage of sporulation. J Gen Microbio/ 1992, 138(12):2609-2618.

42. Partridge SR, Errington J: The importance of morphological events and intercellular interactions in the regulation of prespore-specific gene expression during sporulation in Bacillus subtilis. Mol Microbiol 1993, 8(5):945-955.

43. Camp AH, Losick R: A novel pathway of intercellular signalling in Bacillus subtilis involves a protein with similarity to a component of type III secretion channels. Mol Microbiol 2008, 69(2):402-417.

44. Campo N, Rudner DZ: SpolVB and CtpB are both forespore signals in the activation of the sporulation transcription factor $\sigma^{\mathrm{K}}$ in Bacillus subtilis. J Bacteriol 2007, 189(16):6021-6027.

45. Meisner J, Wang $X$, Serrano M, Henriques AO, Moran CP Jr: A channel connecting the mother cell and forespore during bacterial endospore formation. Proc Natl Acad Sci U S A 2008, 105(39):15100-15105.

46. Kroos L, Kunkel B, Losick R: Switch protein alters specificity of RNA polymerase containing a compartment-specific sigma factor. Science 1989, 243(4890):526-529

47. Ricca E, Cutting S, Losick R: Characterization of bofA, a gene involved in intercompartmental regulation of pro- $\sigma^{\mathrm{K}}$ processing during sporulation in Bacillus subtilis. J Bacteriol 1992, 174(10):3177-3184.

48. Cutting S, Roels S, Losick R: Sporulation operon spolVF and the characterization of mutations that uncouple mother-cell from forespore gene expression in Bacillus subtilis. J Mol Biol 1991, 221(4):1237-1256.

49. Juan $\mathrm{Wu} L$, Errington J: Identification and characterization of a new prespore-specific regulatory gene, rsfA, of Bacillus subtilis. J Bacterio/ 2000, 182(2):418-424.

50. Zheng L, Halberg R, Roels S, Ichikawa H, Kroos L, Losick R: Sporulation regulatory protein GerE from Bacillus subtilis binds to and can activate or repress transcription from promoters for mother-cell-specific genes. J Mol Biol 1992, 226(4):1037-1050.

51. Bagyan I, Hobot J, Cutting S: A compartmentalized regulator of developmental gene expression in Bacillus subtilis. J Bacteriol 1996, 178 (15):4500-4507

52. Halberg R, Kroos L: Sporulation regulatory protein SpollID from Bacillus subtilis activates and represses transcription by both mother-cell-specific forms of RNA polymerase. J Mol Biol 1994, 243(3):425-436.

53. Eichenberger $P$, Fujita M, Jensen ST, Conlon EM, Rudner DZ, Wang ST, Ferguson C, Haga K, Sato T, Liu JS, et al: The program of gene transcription for a single differentiating cell type during sporulation in Bacillus subtilis. PLoS Biol 2004, 2(10):e328.

54. Angert ER, Clements KD: Initiation of intracellular offspring in Epulopiscium. Mol Microbiol 2004, 51(3):827-835.

55. Miller DA, Choat JH, Clements KD, Angert ER: The spollE homolog of Epulopiscium sp. type B is expressed early in intracellular offspring development. J Bacteriol 2011, 193(10):2642-2646.

56. Ward RJ, Clements KD, Choat JH, Angert ER: Cytology of terminally differentiated Epulopiscium mother cells. DNA Cell Biol 2009, 28(2):57-64.

57. Ryter $\mathrm{A}$, Schaeffer $\mathrm{P}$, lonesco H: Classification cytologique, par leur stade blocage, des mutants de sporulation de Bacillus subtilis Marburg. Ann Inst Pasteur 1966, 110:305-315.

58. Pogliano J, Osborne N, Sharp MD, Abanes-De Mello A, Perez A, Sun YL, Pogliano K: A vital stain for studying membrane dynamics in bacteria: a novel mechanism controlling septation during Bacillus subtilis sporulation. Mol Microbiol 1999, 31(4):1149-1159.
59. Guzman P, Westpheling J, Youngman P: Characterization of the promoter region of the Bacillus subtilis spollE operon. J Bacteriol 1988, 170(4):1598-1609.

60. Angert ER, Clements KD, Pace NR: The largest bacterium. Nature 1993, 362 (6417):239-241.

61. Mendell JE, Clements KD, Choat JH, Angert ER: Extreme polyploidy in a large bacterium. Proc Natl Acad Sci U S A 2008, 105(18):6730-6734.

62. Miller DA, Suen G, Bruce D, Copeland A, Cheng JF, Detter C, Goodwin LA, Han CS, Hauser LJ, Land ML, et al: Complete genome sequence of the cellulose-degrading bacterium Cellulosilyticum lentocellum. J Bacterio/ 2011, 193(9):2357-2358.

63. Wang ST, Setlow B, Conlon EM, Lyon JL, Imamura D, Sato T, Setlow P, Losick $\mathrm{R}$, Eichenberger $\mathrm{P}$ : The forespore line of gene expression in Bacillus subtilis. J Mol Biol 2006, 358(1):16-37.

64. Steil L, Serrano M, Henriques AO, Volker U: Genome-wide analysis of temporally regulated and compartment-specific gene expression in sporulating cells of Bacillus subtilis. Microbiology 2005, 151(Pt 2):399-420.

65. Lechat P, Hummel L, Rousseau S, Moszer I: GenoList: an integrated environment for comparative analysis of microbial genomes. Nucleic Acids Res 2008, 36(Database issue):D469-D474.

66. Stephenson $\mathrm{K}$, Hoch JA: Evolution of signalling in the sporulation phosphorelay. Mol Microbiol 2002, 46(2):297-304.

67. Stragier P: A gene odyssey: exploring the genomes of endosporeforming bacteria. In Bacillus subtilis and its closest relatives. Edited by Sonenshein AL, Hoch JA, Losick R. Washington D.C: ASM Press; 2002:519-525.

68. Paredes CJ, Alsaker KV, Papoutsakis ET: A comparative genomic view of clostridial sporulation and physiology. Nat Rev Microbio/ 2005, 3(12):969-978.

69. Steiner E, Dago AE, Young DI, Heap JT, Minton NP, Hoch JA, Young M: Multiple orphan histidine kinases interact directly with SpoOA to control the initiation of endospore formation in Clostridium acetobutylicum. Mol Microbiol 2011, 80(3):641-654

70. Sharpe ME, Errington J: Postseptational chromosome partitioning in bacteria. Proc Natl Acad Sci U S A 1995, 92(19):8630-8634

71. McBride SM, Rubio A, Wang L, Haldenwang WG: Contributions of protein structure and gene position to the compartmentalization of the regulatory proteins $\sigma^{\mathrm{E}}$ and SpollE in sporulating Bacillus subtilis. Mol Microbiol 2005, 57(2):434-451.

72. Chary VK, Xenopoulos P, Piggot PJ: Blocking chromosome translocation during sporulation of Bacillus subtilis can result in prespore-specific activation of $\sigma^{\mathrm{G}}$ that is independent of $\sigma^{\mathrm{E}}$ and of engulfment. J Bacteriol 2006, 188(20):7267-7273.

73. Eldar A, Chary VK, Xenopoulos P, Fontes ME, Loson OC, Dworkin J, Piggot PJ, Elowitz MB: Partial penetrance facilitates developmental evolution in bacteria. Nature 2009, 460(7254):510-514.

74. Saller MJ, Fusetti F, Driessen AJ: Bacillus subtilis SpollIJ and YqjG function in membrane protein biogenesis. J Bacteriol 2009, 191(21):6749-6757.

75. Setlow B, McGinnis KA, Ragkousi K, Setlow P: Effects of major sporespecific DNA binding proteins on Bacillus subtilis sporulation and spore properties. J Bacteriol 2000, 182(24):6906-6912.

76. Brown DP, Ganova-Raeva L, Green BD, Wilkinson SR, Young M, Youngman P: Characterization of spoOA homologues in diverse Bacillus and Clostridium species identifies a probable DNA-binding domain. Mol Microbiol 1994, 14(3):411-426

77. Dürre P: Ancestral sporulation initiation. Mol Microbiol 2011, 80(3):584-587.

78. Ravagnani A, Jennert KC, Steiner E, Grunberg R, Jefferies JR, Wilkinson SR, Young DI, Tidswell EC, Brown DP, Youngman P, et al: Spo0A directly controls the switch from acid to solvent production in solvent-forming clostridia. Mol Microbiol 2000, 37(5):1172-1185.

79. Popham DL, Stragier P: Binding of the Bacillus subtilis spolVCA product to the recombination sites of the element interrupting the $\sigma^{\mathrm{K}}$-encoding gene. Proc Natl Acad Sci U S A 1992, 89(13):5991-5995.

80. Stragier $P$, Kunkel B, Kroos L, Losick R: Chromosomal rearrangement generating a composite gene for a developmental transcription factor. Science 1989, 243(4890):507-512.

81. Cutting S, Driks A, Schmidt R, Kunkel B, Losick R: Forespore-specific transcription of a gene in the signal transduction pathway that governs Pro- $\sigma^{\mathrm{K}}$ processing in Bacillus subtilis. Genes Dev 1991, 5(3):456-466.

82. Frandsen N, Stragier P: Identification and characterization of the Bacillus subtilis spollP locus. J Bacteriol 1995, 177(3):716-722. 
83. Margolis PS, Driks A, Losick R: Sporulation gene spollB from Bacillus subtilis. J Bacteriol 1993, 175(2):528-540.

84. Liu NJ, Dutton RJ, Pogliano K: Evidence that the SpollIE DNA translocase participates in membrane fusion during cytokinesis and engulfment. $\mathrm{Mol}$ Microbiol 2006, 59(4):1097-1113.

85. Sharp MD, Pogliano K: The membrane domain of SpolllE is required for membrane fusion during Bacillus subtilis sporulation. J Bacteriol 2003, 185 (6):2005-2008

86. Asai K, Takamatsu H, Iwano M, Kodama T, Watabe K, Ogasawara N: The Bacillus subtilis yabQ gene is essential for formation of the spore cortex. Microbiology 2001, 147(Pt 4):919-927.

87. van Ooij $C$, Eichenberger $P$, Losick R: Dynamic patterns of subcellular protein localization during spore coat morphogenesis in Bacillus subtilis. J Bacteriol 2004, 186(14):4441-4448.

88. Piggot PJ, Coote JG: Genetic aspects of bacterial endospore formation Bacteriol Rev 1976, 40(4):908-962.

89. Amaya $\mathrm{E}$, Khvorova $\mathrm{A}$, Piggot PJ: Analysis of promoter recognition in vivo directed by $\sigma^{F}$ of Bacillus subtilis by using random-sequence oligonucleotides. J Bacteriol 2001, 183(12):3623-3630.

90. Daniel RA, Errington J: Cloning, DNA sequence, functional analysis and transcriptional regulation of the genes encoding dipicolinic acid synthetase required for sporulation in Bacillus subtilis. J Mol Biol 1993, 232 (2):468-483.

91. Errington J: Bacillus subtilis sporulation: regulation of gene expression and control of morphogenesis. Microbiol Rev 1993, 57(1):1-33.

92. Alvarez Z, Abel-Santos E: Potential use of inhibitors of bacteria spore germination in the prophylactic treatment of anthrax and Clostridium difficile-associated disease. Expert Rev Anti Infect Ther 2007, 5(5):783-792.

93. Myers EW, Sutton GG, Delcher AL, Dew IM, Fasulo DP, Flanigan MJ, Kravitz SA, Mobarry CM, Reinert KH, Remington KA, et al: A whole-genome assembly of Drosophila. Science 2000, 287(5461):2196-2204.

94. Sutton GG, White O, Adams MD, Kerlavage AR: TIGR Assembler: A new tool for assembling large shotgun sequencing projects. Genome Sequencing Tech 1995, 1:9-19.

95. Delcher AL, Bratke KA, Powers EC, Salzberg SL: Identifying bacterial genes and endosymbiont DNA with Glimmer. Bioinformatics 2007, 23(6):673-679.

96. Altschul SF, Madden TL, Schaffer AA, Zhang J, Zhang Z, Miller W, Lipman DJ: Gapped BLAST and PSI-BLAST: a new generation of protein database search programs. Nucleic Acids Res 1997, 25(17):3389-3402.

97. Lagesen K, Hallin P, Rodland EA, Staerfeldt HH, Rognes T, Ussery DW: RNAmmer: consistent and rapid annotation of ribosomal RNA genes. Nucleic Acids Res 2007, 35(9):3100-3108.

98. Lowe TM, Eddy SR: tRNAscan-SE: a program for improved detection of transfer RNA genes in genomic sequence. Nucleic Acids Res 1997, 25(5):955-964

99. Tatusov RL, Galperin MY, Natale DA, Koonin EV: The COG database: a tool for genome-scale analysis of protein functions and evolution. Nucleic Acids Res 2000, 28(1):33-36.

100. Marchler-Bauer A, Anderson JB, Derbyshire MK, DeWeese-Scott C, Gonzales NR, Gwadz M, Hao L, He S, Hurwitz DI, Jackson JD, et al: CDD: a conserved domain database for interactive domain family analysis. Nucleic Acids Res 2007, 35(Database issue):D237-D240.

101. Sievers F, Wilm A, Dineen D, Gibson TJ, Karplus K, Li W, Lopez R, McWilliam $H$, Remmert M, Soding J, et al: Fast, scalable generation of high-quality protein multiple sequence alignments using Clustal Omega. Mol Syst Biol 2011, 7:539.

doi:10.1186/1471-2164-13-265

Cite this article as: Miller et al:: The genomic basis for the evolution of a novel form of cellular reproduction in the bacterium Epulopiscium. BMC Genomics 2012 13:265.

\section{Submit your next manuscript to BioMed Central and take full advantage of:}

- Convenient online submission

- Thorough peer review

- No space constraints or color figure charges

- Immediate publication on acceptance

- Inclusion in PubMed, CAS, Scopus and Google Scholar

- Research which is freely available for redistribution

Submit your manuscript at www.biomedcentral.com/submit
C Biomed Central 